\title{
Technical Note: The Simple Diagnostic Photosynthesis and Respiration Model (SDPRM)
}

\author{
B. Badawy ${ }^{1, *}$, C. Rödenbeck ${ }^{1}$, M. Reichstein ${ }^{1}$, N. Carvalhais ${ }^{1}$, and M. Heimann ${ }^{1}$ \\ ${ }^{1}$ Max Planck Institute for Biogeochemistry, Jena, Germany \\ *now at: Climate Research Division, Environment Canada, Toronto, Canada
}

Correspondence to: B. Badawy (bakr.badawy@ec.gc.ca)

Received: 14 June 2012 - Published in Biogeosciences Discuss.: 30 October 2012

Revised: 26 August 2013 - Accepted: 27 August 2013 - Published: 11 October 2013

\begin{abstract}
We present a Simple Diagnostic Photosynthesis and Respiration Model (SDPRM) that has been developed based on pre-existing formulations. The photosynthesis model is based on the light use efficiency logic for calculating the gross primary production (GPP), while the ecosystem respiration $\left(R_{\text {eco }}\right)$ is a modified version of an Arrhenius-type equation. SDPRM is driven by satellite-derived fAPAR (fraction of Absorbed Photosynthetically Active Radiation) and climate data from the National Center for Environmental Prediction/National Center for Atmospheric Research Reanalysis (NCEP/NCAR). The model estimates 3-hourly values of GPP for seven major biomes and daily $R_{\text {eco }}$. The motivation is to provide a priori fields of surface $\mathrm{CO}_{2}$ fluxes with fine temporal and spatial scales for atmospheric $\mathrm{CO}_{2}$ inversions. The estimated fluxes from SDPRM showed that the model is capable of producing flux estimates consistent with the ones inferred from atmospheric $\mathrm{CO}_{2}$ inversion or simulated from process-based models. In this Technical Note, different analyses were carried out to test the sensitivity of the estimated fluxes of GPP and $R_{\text {eco }}$ to their driving forces. The spatial patterns of the climatic controls (temperature, precipitation, water) on the interannual variability of GPP are consistent with previous studies, even though SDPRM has a very simple structure and few adjustable parameters and hence it is much easier to modify in an inversion than more sophisticated process-based models. In SDPRM, temperature is a limiting factor for the interannual variability of $R_{\text {eco }}$ over cold boreal forest, while precipitation is the main limiting factor of $R_{\text {eco }}$ over the tropics and the southern hemisphere, consistent with previous regional studies.
\end{abstract}

\section{Introduction}

The terrestrial biosphere plays an important role in the regional and the global carbon cycle, and thus the climate system. Therefore, understanding the role of the land biosphere in the global carbon budget is necessary, particularly the response and feedback of carbon fluxes to climatic controls. The terrestrial carbon cycle involves a set of biogeochemical processes that vary on a wide range of spatial and temporal scales. These processes can either reduce the level of atmospheric carbon or increase it, and are themselves sensitive to changes in climate, atmospheric $\mathrm{CO}_{2}$, water availability, and land use. To understand the role of the terrestrial biosphere in the global carbon cycle, and thus their behavior in the future, it is crucial to quantify the processes that transfer carbon between the terrestrial biosphere and the atmosphere and their relations to the drivers.

Several techniques have been used to estimate carbon fluxes. Direct measurements of carbon fluxes using eddy covariance methods are an essential approach to measure and monitor carbon fluxes at local scales with high temporal resolution (Baldocchi, 2003; Baldocchi et al., 2012). These measurements only represent the fluxes at the scale of the tower footprint, usually on the order of a few square kilometers or less (Baldocchi, 2003). There are many regions of the globe, the tropics in particular, where measurements are incomplete or entirely lacking. Thus, the coverage as well as the accuracy of these measurements is not sufficient for obtaining confidence at regional/global scale flux estimates (Friend et al., 2007). 
As an alternative source of information, atmospheric $\mathrm{CO}_{2}$ measurements have played a key role in assessing source/sink distributions on global scales using atmospheric $\mathrm{CO}_{2}$ inverse modeling (top-down approach) (e.g., Enting et al. (1995); Kaminski et al. (2002); Bousquet et al. (2000); Rödenbeck et al. (2003); Baker et al. (2006)). However, consistent multi-year observations are currently only available at a discrete set of surface stations, which only provide largescale information on surface fluxes. Moreover, the atmospheric concentration only reflects the combined effect of all processes acting at the surface (natural and anthropogenic). Accordingly, they provide little or no information about the underlying processes responsible for the estimated fluxes.

Terrestrial biosphere models (bottom-up approaches) also simulate the carbon fluxes between the atmosphere and the terrestrial system. These models range in complexity from simple regression "statistical" models to more complex process-based models. The simple statistical biosphere models are mainly based on empirical relations between one or more estimates of biological processes (e.g., soil respiration) and important climatic variables (e.g., temperature, precipitation) (e.g., Raich and Schlesinger (1992); Lloyd and Taylor (1994); Reichstein et al. $(2003,2005))$. On the other hand, the process-based models integrate knowledge of physiological and ecological processes to model the response of the system to environmental changes (Potter et al., 1993, 2012; McGuire et al., 2001; Sitch et al., 2008). Several studies have shown that the interannual variations (IAV) in ecosystem productivity simulated by different ecosystem models show large differences (McGuire et al., 2001; Schwalm et al., 2010; Keenan et al., 2012). This is because different models have different formulations representing ecosystem processes and environmental stresses that dominate the interannual variability. The validation of the terrestrial biosphere models is difficult on a large scale, due to difficulties in scaling up small-scale measurements (e.g., eddy flux measurements)

In the light of the above, terrestrial biosphere models (bottom-up) and inverse models (top-down) have been combined into a multiple-constraint approach (e.g., Kaminski et al. (2002); Rayner et al. (2005); Turner et al. (2011)). In such an approach, key parameters of the biosphere model are optimized such that the mismatch between the modeled and the observed atmospheric $\mathrm{CO}_{2}$ concentrations is minimized. This way, both the information on finer spatio-temporal resolution from the biosphere models and the large-scale atmospheric information is exploited. Optimizing model parameters instead of the fluxes themselves potentially allows more understanding about individual underlying processes.

Kaminski et al. (2002) introduced a systematic method for optimizing parameters. They optimized the controlling parameters of the Simple Diagnostic Biosphere Model (SDBM) introduced by Knorr and Heimann (1995) with respect to the seasonal cycle of atmospheric $\mathrm{CO}_{2}$ concentrations. These optimized parameters are then used to run the model to predict diagnostic quantities of interest, such as net primary produc- tivity (NPP). A more complex approach, usually known as a carbon cycle data assimilation system (CCDAS), was introduced by Scholze et al. (2003) and Rayner et al. (2005). In CCDAS, they extended the work of Kaminski et al. (2002) by replacing SDBM by the more sophisticated prognostic terrestrial biosphere model, the Biosphere Energy Transfer Hydrology Scheme (BETHY) (Knorr, 2000). The model can be run in prognostic mode to predict the behavior of the terrestrial biosphere under climate change. As the BETHY process model is not linear, the minimization algorithm in the CCDAS is a complex task.

We envisage to follow this multiple-constraint approach, but using a diagnostic biosphere model that is as simple as possible, while still capturing as much as possible fine-scale structure of the surface fluxes as provided in available driving fields, and involving only a small set of parameters that can modify the model behavior on larger scales. As a first step towards this, the aim of this Technical Note is to present the Simple Diagnostic Photosynthesis and Respiration Model (SDPRM) that we developed based on pre-existing formulations. To some extent, SDPRM is set up in a process-oriented way, but nevertheless essentially as an empirical relationship between net ecosystem exchange (NEE) and a set of driving variables expected to be the essential controls. By coupling this model with the Jena inversion system (in a follow-up study), the model parameters will be optimized based on atmospheric $\mathrm{CO}_{2}$ data; this coupling will be described in a subsequent paper.

The outline of the Technical Note is as follows: Sect. 2 describes the empirical equations of the Simple Diagnostic Photosynthesis and Respiration Model (SDPRM) and the data used. Section 3 shows and discusses the results of the model. A global assessment of the importance of the climatic controls in limiting the interannual variability of GPP and $R_{\text {eco }}$ are presented and discussed in Sect. 3.3.

\section{Simple Diagnostic Photosynthesis and Respiration Model (SDPRM)}

The NEE of $\mathrm{CO}_{2}$ is the balance between the photosynthetic $\mathrm{CO}_{2}$ uptake by plants through gross primary production (GPP) and $\mathrm{CO}_{2}$ emission through Ecosystem Respiration $\left(R_{\text {eco }}\right)$ by plants and soil, (NEE $\left.=R_{\text {eco }}-\mathrm{GPP}\right)$. Many diurnal and seasonal patterns of atmospheric $\mathrm{CO}_{2}$ concentration are dominated by only these two processes (Denning et al., 1996; Heimann et al., 1998). The Simple Diagnostic Photosynthesis and Respiration Model (SDPRM) expresses these two processes as an instantaneous function of the fraction of Absorbed Photosynthetically Active Radiation (fAPAR), and climate drivers (temperature, precipitation, and radiation). Additional processes including fire, dissolved organic carbon (DOC) and dissolved inorganic carbon (DIC) losses in rivers, erosion, and land use changes also influence the interannual and decadal dynamics in atmospheric $\mathrm{CO}_{2}$ 
(Canadell et al., 2000; Pacala et al., 2001; Stoy et al., 2005; Randerson et al., 2005; van der Werf et al., 2010), but are not explicitly included into the model. SDPRM estimates 3hourly values of GPP and daily $R_{\text {eco }}$ over the period (19822006) on a grid-scale resolution ( $4^{\circ}$ latitude $\times 5^{\circ}$ longitude).

\subsection{Data}

\subsubsection{GIMMS NDVI}

SDPRM requires two types of satellite-based information: a land cover classification into plant functional types (PFTs), and fAPAR as a proxy for vegetation greenness. Previous studies show that changes in the normalized difference vegetation index (NDVI), the contrast between red and nearinfrared reflectances of vegetation, indicate changes in vegetation conditions proportional to fAPAR (Sellers, 1985; Nemani and Running, 1989; Los et al., 2000). Therefore, the global NDVI data set produced by the Global Inventory Modeling and Mapping Studies (GIMMS) - version $\mathrm{g}$ - is used to estimate fAPAR using an algorithm described by Los et al. (2000) (see Appendix A). The GIMMS NDVI data are available at the Global Land Cover Facility http://glcf.umiacs. umd.edu/ at a biweekly temporal resolution from 1982 to 2006 and a spatial resolution of $8 \mathrm{~km} \times 8 \mathrm{~km}$. The GIMMS NDVI data are derived from imagery obtained from the Advanced Very High Resolution Radiometer (AVHRR) instrument onboard the NOAA satellite series 7, 9, 11, 14, 16 and 17 (Tucker et al., 2005).

GIMMS NDVI data are chosen because they cover a longer time period (1982-2006) compared to other satellite data sources (e.g., MODIS). The data are collected by a consistent series of instruments. In addition, several independent studies used earlier versions of the GIMMS NDVI data and showed a reasonable agreement between GIMMS NDVI and other measures of vegetation (Davenport and Nicholson, 1993; Malmstrom et al., 1997; D'Arrigo et al., 2000). Nevertheless, as with any satellite-based measurement, GIMMS NDVI suffers from numerous deficiencies including sensor degradation, cloud/snow contamination, limitation due to viewing geometry, and atmospheric effects. Therefore, GIMMS NDVI has been corrected by the data provider for some effects which are not related to vegetation change (Tucker et al., 2005). Nevertheless, it is still likely that after the corrections some contamination remains. Some sources of errors in the NDVI data set are not accounted for (i.e., soil background reflectance) as well. Therefore, GIMMS NDVI spatial/temporal variations for a certain region/time are affected by these corrections/errors, producing some variations, which may not related to actual variations in the vegetation. These errors in NDVI translate directly to errors in fAPAR.

\subsubsection{Land Cover Classification}

To produce a land cover classification into plant functional types (PFTs), the synergetic land cover data set (SYNMAP) from Jung et al. (2006) are projected to the GIMMS NDVI grid $(8 \mathrm{~km} \times 8 \mathrm{~km})$. Subsequently, its classifications are aggregated into seven major PFTs (see Table 1, Fig. 1, and Fig. 2). As a criterion of this aggregation, the spatial extent of the aggregated PFTs should not be too small in order to be distinguishable by the envisaged atmospheric observations through the atmospheric inversion calculations (followup study). Therefore, classes of limited extent are joined to others of similar phenological properties. Also, all deciduous and mixed forests are joined into DxF (see Table 1) (despite ecological differences between them). The layout of the classes is a compromise between spatial diversity of these responses (demanding many classes) and the limited information available in the data (demanding few classes). For each PFT, a density map (fractional cover) $0 \leq \varrho_{\mathrm{PFT}}(x, y) \leq 1$ is obtained by summing up the density maps of the original land-surface classes:

$\varrho_{\mathrm{PFT}}(x, y)=\sum_{\text {class } \in \mathrm{PFT}} \varrho_{\text {class }}(x, y)$.

The density map of all (non-ignored) land cover classes is written as:

$\varrho_{\text {veg }}(x, y)=\sum_{\text {PFT }} \varrho_{\text {PFT }}(x, y)$.

where latitude is the $y$ axis, and longitude is the $x$ axis.

\subsubsection{Meteorological data}

SDPRM also needs meteorological fields (temperature, precipitation, shortwave radiation, specific humidity) as input, taken from the improved reanalysis data set from the $\mathrm{Na}-$ tional Center for Environmental Prediction/National Center for Atmospheric Research Reanalysis (NCEP/NCAR) (Kalnay et al., 1996) for the period 1982-2006. The data set consists of a reanalysis of the global observational network of meteorological variables (wind, temperature, pressure, humidity). The NCEP/NCAR data set are T62 gaussian grid $(192 \times 94)$ with temporal resolution of 6 hours or daily. It is aggregated to the resolution of $4^{\circ}$ latitude $\times 5^{\circ}$ longitude as in SDPRM.

\subsection{Photosynthesis model}

GPP is modeled as a function of climatic and soil variables, and uses satellite-derived estimates of the vegetation's lightabsorbing properties (e.g., Randerson et al. (1996); Sellers et al. (1996b); Kaminski et al. (2002); van der Werf et al. (2004)). In general, these models are known as light use efficiency (LUE) models, first introduced by (Monteith, 1977). Here, we follow MOD17, primary production products algorithm for calculating GPP (Running et al., 1999; 
Table 1. SYNMAP (Jung et al., 2006) land cover classification and its aggregation into seven major PFTs. See Table 2 for the descriptive abbreviations used for the PFTs.

\begin{tabular}{|c|c|c|c|c|}
\hline \multicolumn{4}{|c|}{ SYNMAP (Jung et al., 2006) } & \multirow{2}{*}{$\begin{array}{c}7 \text { major PFT's } \\
\text { PFT(index) }\end{array}$} \\
\hline Class & Life forms & Tree leaf type & Tree leaf longevity & \\
\hline 1 & Trees & Needle & Evergreen & ENF (1) \\
\hline 2 & Trees & Needle & Deciduous & $\operatorname{DxF}(3)$ \\
\hline 3 & Trees & Needle & Mixed & DxF (3) \\
\hline 4 & Trees & Broad & Evergreen & EBF (2) \\
\hline 5 & Trees & Broad & Deciduous & DxF (3) \\
\hline 6 & Trees & Broad & Mixed & DxF (3) \\
\hline 7 & Trees & Mixed & Evergreen & DxF (3) \\
\hline 8 & Trees & Mixed & Deciduous & $\operatorname{DxF}(3)$ \\
\hline 9 & Trees & Mixed & Mixed & $\operatorname{DxF}(3)$ \\
\hline 10 & Trees \& Shrubs & Needle & Evergreen & ENF (1) \\
\hline 11 & Trees \& Shrubs & Needle & Deciduous & $\operatorname{DxF}(3)$ \\
\hline 12 & Trees \& Shrubs & Needle & Mixed & DxF (3) \\
\hline 13 & Trees \& Shrubs & Broad & Evergreen & SAV (5) \\
\hline 14 & Trees \& Shrubs & Broad & Deciduous & SAV (5) \\
\hline 15 & Trees \& Shrubs & Broad & Mixed & SAV (5) \\
\hline 16 & Trees \& Shrubs & Mixed & Evergreen & SAV (5) \\
\hline 17 & Trees \& Shrubs & Mixed & Deciduous & SAV (5) \\
\hline 18 & Trees \& Shrubs & Mixed & Mixed & DxF (3) \\
\hline 19 & Trees \& Grasses & Needle & Evergreen & ENF (1) \\
\hline 20 & Trees \& Grasses & Needle & Deciduous & DxF (3) \\
\hline 21 & Trees \& Grasses & Needle & Mixed & DxF (3) \\
\hline 22 & Trees \& Grasses & Broad & Evergreen & $\operatorname{EBF}(2)$ \\
\hline 23 & Trees \& Grasses & Broad & Deciduous & SAV (5) \\
\hline 24 & Trees \& Grasses & Broad & Mixed & SAV (5) \\
\hline 25 & Trees \& Grasses & Mixed & Evergreen & $\operatorname{DxF}(3)$ \\
\hline 26 & Trees \& Grasses & Mixed & Deciduous & $\operatorname{DxF}(3)$ \\
\hline 27 & Trees \& Grasses & Mixed & Mixed & SAV (5) \\
\hline 28 & Trees \& Crops & Needle & Evergreen & CRO (7) \\
\hline 29 & Trees \& Crops & Needle & Deciduous & CRO (7) \\
\hline 30 & Trees \& Crops & Needle & Mixed & CRO (7) \\
\hline 31 & Trees \& Crops & Broad & Evergreen & CRO (7) \\
\hline 32 & Trees \& Crops & Broad & Deciduous & CRO (7) \\
\hline 33 & Trees \& Crops & Broad & Mixed & CRO (7) \\
\hline 34 & Trees \& Crops & Mixed & Evergreen & CRO (7) \\
\hline 35 & Trees \& Crops & Mixed & Deciduous & CRO (7) \\
\hline 36 & Trees \& Crops & Mixed & Mixed & CRO (7) \\
\hline 37 & Shrubs & - & - & SHR (4) \\
\hline 38 & Shrubs \& Grasses & - & - & SHR (4) \\
\hline 39 & Shrubs \& Crops & - & - & SHR (4) \\
\hline 40 & Shrubs \& Barren & - & - & SHR (4) \\
\hline 41 & Grasses & - & - & GRS (6) \\
\hline 42 & Grasses \& Crops & - & - & GRS (6) \\
\hline 43 & Grasses \& Barren & - & - & GRS (6) \\
\hline 44 & Crops & - & - & CRO (7) \\
\hline 45 & Barren & - & - & (ignored) (8) \\
\hline 46 & Urban & - & - & (ignored) (8) \\
\hline 47 & Snow \& Ice & - & - & (ignored) (8) \\
\hline
\end{tabular}




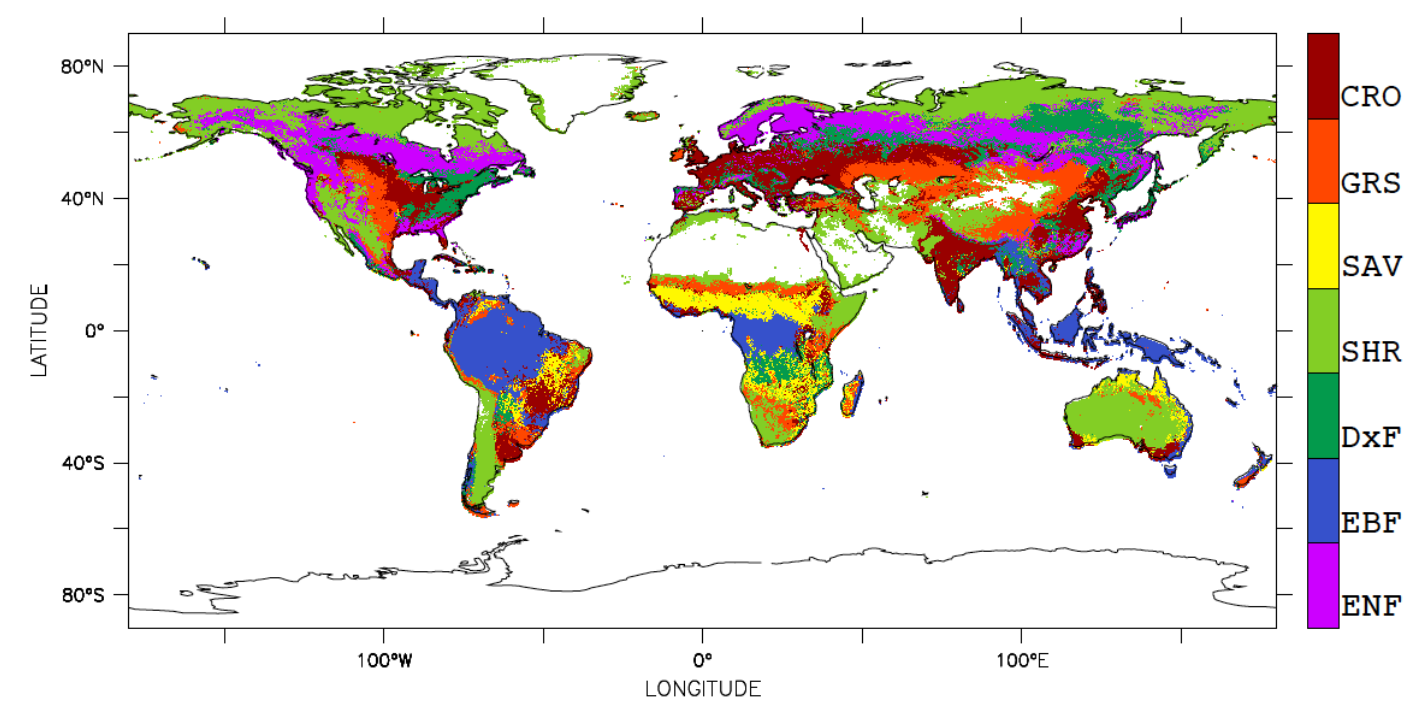

Fig. 1. The SYNMAP (Jung et al., 2006) land cover data set aggregated into seven major PFTs in the GIMMS NDVI grid ( $8 \mathrm{~km} \times 8 \mathrm{~km})($ see Table 1). PFT labels are described in Table 2. The fractional cover map for each PFT with a spatial resolution of $4^{\circ}$ latitude $\times 5^{\circ}$ longitude are shown if Fig. 2.

Heinsch et al., 2003 [accessed 31 December 2009]; Running et al., 2004). The 3-hourly values of GPP is calculated as

$\mathrm{GPP}=\mathrm{PAR} \times \mathrm{fAPAR} \times \varepsilon$,

where $\varepsilon(\mathrm{gC} / \mathrm{MJ})$ is the light use efficiency, fAPAR is the fraction of absorbed PAR, and PAR is calculated as $45 \%$ of incident solar radiation $I$ (Nobel, 1991) as

$\operatorname{PAR}(x, y, t)=0.45 \cdot I(x, y, t)$,

where latitude is the $y$ axis, longitude is the $x$ axis, and time is the $t$ axis. The $\varepsilon$ is calculated by attenuating maximum light use efficiency $\varepsilon_{\max }$ (mass of assimilated carbon per unit energy of absorbed radiation) via the effect of temperature $\left(g_{T}\right)$ and vapor pressure deficit $\left(g_{\mathrm{VPD}}\right)$ factors as

$\varepsilon=\varepsilon_{\max } \cdot g_{T} \cdot g_{\mathrm{VPD}}$.

The attenuation factors $g_{T}$ and $g_{\mathrm{VPD}}$ are simple ramp functions of daily minimum temperature $T_{\min }$ and vapor pressure deficit VPD (difference between actual partial pressure of water vapor and saturation water vapor pressure, in $\mathrm{Pa}$ ). The dependence on daytime mean VPD is defined as

$g_{\mathrm{VPD}}= \begin{cases}1, & \mathrm{VPD}<\mathrm{VPD}_{1} \\ \frac{\mathrm{VPD}_{0}-\mathrm{VPD}}{\mathrm{VPD}_{0}-\mathrm{VPD}_{1}}, & \mathrm{VPD} D_{1}<V P D<\mathrm{VPD}_{0} . \\ 0, & \mathrm{VPD}>\mathrm{VPD}_{0}\end{cases}$

The dependence on daily minimum temperature is defined as

$g_{T}= \begin{cases}0, & T_{\min }<T_{\min , 0} \\ \frac{T_{\min }-T_{\min , 0}}{T_{\min , 1}-T_{\min , 0},}, & T_{\min , 0}<T_{\min }<T_{\min , 1} \\ 1, & T_{\min }>T_{\min , 1}\end{cases}$ with $T_{\min , 0}=-8{ }^{\circ} \mathrm{C}$. The values of $T_{\min , 1}, \mathrm{VPD}_{1}$ and $\mathrm{VPD}_{0}$ are given in Table 2 for each PFT. Then, GPP formula for each PFT can be written as

$$
\begin{aligned}
\operatorname{GPP}_{\mathrm{PFT}}(x, y, t)= & \varepsilon_{\text {max } \mathrm{PFT}} \cdot \varrho_{\mathrm{PFT}}(x, y) \\
& \cdot f \operatorname{PAR}_{\mathrm{PFT}}(x, y, t) \cdot \operatorname{PAR}(x, y, t) \\
& \cdot g_{\mathrm{VPDPFT}}(x, y, t) \cdot g_{T_{\mathrm{PFT}}}(x, y, t),
\end{aligned}
$$

where $\varrho_{\mathrm{PFT}}(x, y)$ is the density map (fractional cover) for each PFT (see Eq. (1)). The values of $\varepsilon_{\text {maxpFT }}$ are given in Table 2 for each PFT. Incident radiation $I(x, y, t)$ is calculated from the downward shortwave radiation $I_{\mathrm{SW}}(\mathrm{x}, \mathrm{y}, \mathrm{t})$ from NCEP meteorological reanalysis (Appendix B). Finally, $\operatorname{VPD}(x, y, t)$ is calculated as a daytime mean from specific humidity $q\left(\mathrm{~kg} \mathrm{~kg}^{-1}\right)$, surface pressure $p \approx 101300 \mathrm{~Pa}$, air temperature at $2 \mathrm{~m}$ height $T\left({ }^{\circ} \mathrm{C}\right)$, and the ratio $\kappa=0.62197$ of the molar masses of water vs. air (Appendix C).

\subsection{Ecosystem respiration model}

The respiration model comprises both autotrophic and heterotrophic respiration because, due to similar dependencies on driving data, it is not expected that the signals from both can be separated from the atmospheric $\mathrm{CO}_{2}$ measurements (by the envisaged coupling the model to the inverse model in a follow up study). Following the formulations introduced by Lloyd and Taylor (1994) and Raich et al. (2002) and the modification made by Reichstein et al. (2003), the daily values of Ecosystem Respiration $\left(R_{\text {eco }}\right)$ are calculated over all non-ignored land cover classes using the following 

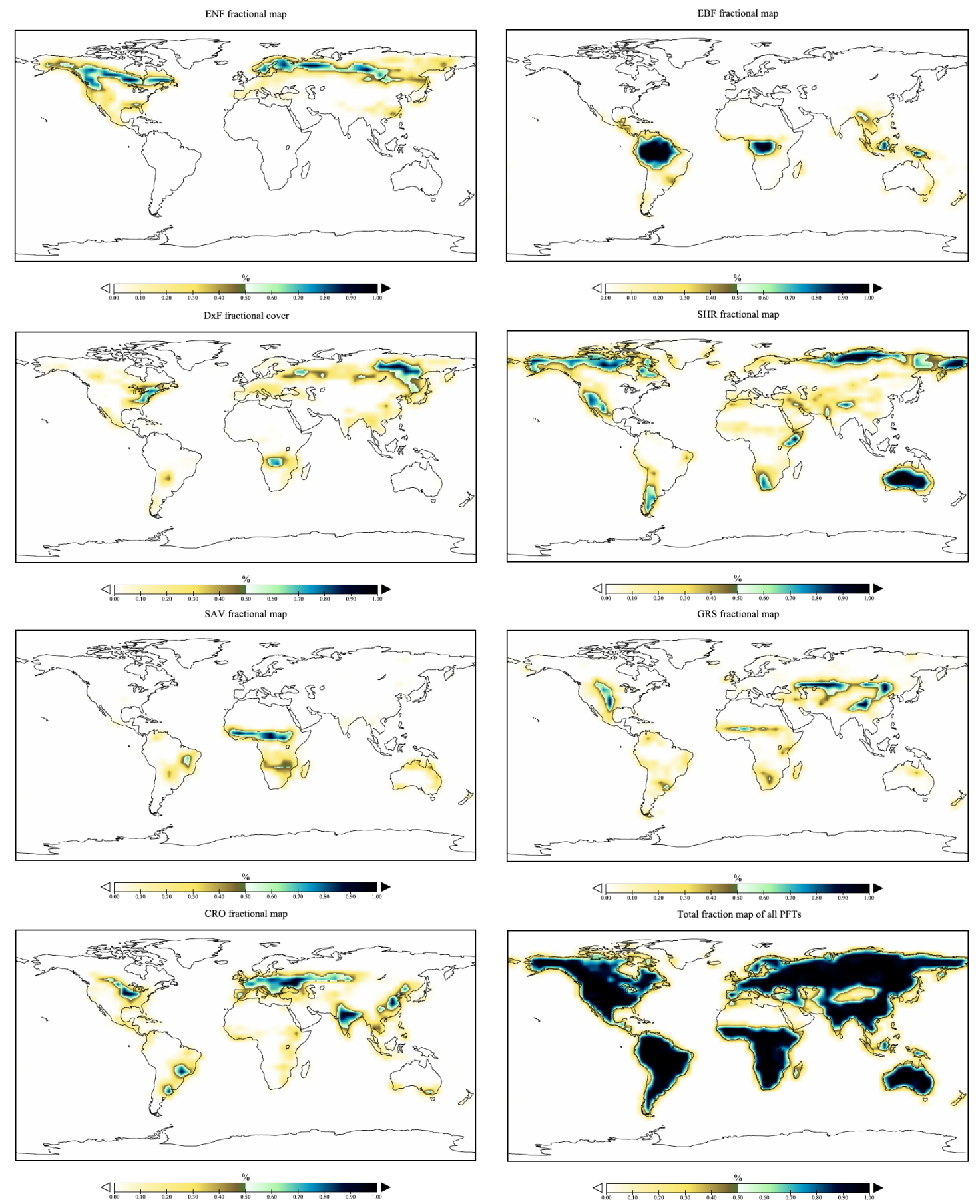

Fig. 2. Fractional cover map for each Plant Function Type PFT with a spatial resolution of $4^{\circ}$ latitude $\times 5^{\circ}$ longitude. The total fractional cover of PFTs is shown in the lower right panel.

equations:

$$
\begin{aligned}
R_{\mathrm{eco}}(x, y, t)= & \left(R_{0}+R_{\mathrm{LAI}} \cdot r_{\mathrm{LAI}}(x, y)\right) \varrho_{\mathrm{veg}}(x, y) \\
& \cdot r_{T}[E, T(x, y, t)] \\
& \cdot r_{P}\left[P_{0}, K, P(x, y, t)\right]
\end{aligned}
$$

where $R_{0}$ (set to $0.8 \mathrm{gC} \mathrm{m}^{-2} \mathrm{~d}^{-1}$ ) is the base respiration rate at the reference temperature, and $R_{\mathrm{LAI}}$ (set to 2.50 $\left.\mathrm{gC} \mathrm{m}^{-2} \mathrm{~d}^{-1}\right)$ is the respiration rate on maximum leaf area in$\operatorname{dex}\left(\mathrm{LAI}_{\max }\right) \cdot \varrho_{\mathrm{veg}}(x, y)$ is a density map of all non-ignored land cover classes (Eq. (2)). The parameters $R_{0}$ and $R_{\mathrm{LAI}}$ are assumed constant over all PFTs because there is no solid 
Table 2. Descriptive abbreviations used for PFTs and the values of PFT-dependent parameters of the photosynthesis model. $\varepsilon_{\text {max }}$ : maximum light use efficiency per PFT, $T_{\text {min, } 1 \text { PFT }}$ : the daily minimum temperature at which $\varepsilon=0.0$ (at any VPD), VPD 1 PFT: the daylight average vapor pressure deficit at which $\varepsilon=0.0$ (at any $T_{\min }$ ), $\mathrm{VPD}_{0 \mathrm{PFT}}$ : the daylight average vapor pressure deficit at which $\varepsilon=\varepsilon \max ($ for optimal $\left.T_{\min }\right)$. The values of the parameters are modified from the Biome Properties Look-Up Table (BPLUT) for MOD17 (Heinsch et al., 2003 [accessed 31 December 2009]).

\begin{tabular}{llllll}
\hline Abbreviation (index) & Class full name & $\begin{array}{l}\varepsilon_{\mathrm{PFT}} \\
(\mathrm{gC} / \mathrm{MJ})\end{array}$ & $\begin{array}{l}T_{\min , 1 \mathrm{PFT}} \\
\left(^{\circ}\right) \mathrm{C}\end{array}$ & $\begin{array}{l}\mathrm{VPD}_{1 \mathrm{PFT}} \\
(\mathrm{Pa})\end{array}$ & $\begin{array}{l}\mathrm{VPD}_{\text {0PFT }} \\
(\mathrm{Pa})\end{array}$ \\
\hline ENF (1) & Evergreen needle & 1.0 & 8.3 & 650 & 3100 \\
EBF (2) & Evergreen broadleaf & 1.0 & 9.1 & 1100 & 3600 \\
DxF (3) & Deciduous/mixed forest & 1.2 & 9.5 & 935 & 3350 \\
SHR (4) & Shrubland & 0.8 & 8.7 & 970 & 4100 \\
SAV (5) & Savanna & 0.8 & 11.4 & 1100 & 5000 \\
GRS (6) & Grassland & 0.6 & 12.0 & 1000 & 5000 \\
CRO (7) & Cropland & 1.1 & 12.0 & 930 & 4100 \\
\hline
\end{tabular}

information on how to break them down spatially (Reichstein et al., 2003; Migliavacca et al., 2011). The leaf area index dependence $\left(r_{\mathrm{LAI}}(x, y)\right)$ is calculated as the average of the yearly maximum fAPAR value (Los et al., 2000) as

$r_{\mathrm{LAI}}(x, y)=\overline{\max (\operatorname{fAPAR}(x, y, t))}$.

The temperature dependence is calculated as

$r_{T}[E, T]=\exp \left(-E\left[\frac{1}{T-T_{0}}-\frac{1}{T_{r e f}-T_{0}}\right],\right)$,

where $T\left({ }^{\circ} \mathrm{C}\right)$ is the daily temperature at $2 \mathrm{~m}$ obtained from NCEP/NCAR data set, $E=135 \mathrm{~K}$ (the activation energy parameter of Lloyd and Taylor (1994)), $T_{0}=-46^{\circ} \mathrm{C}$ (minimum temperature) as in Lloyd and Taylor (1994) and $T_{r e f}=13^{\circ} \mathrm{C}$ (reference temperature, taken from the 1901-2002 mean of the CRU data set over land, available at the University of East Anglia Climatic Research Unit (CRU) (http://www.cru. uea.ac.uk/). The precipitation dependence is written as

$r_{P}\left[P_{0}, K, P\right]=\frac{P+P_{0}}{P+P_{0}+K}$,

where $P$ ( $\mathrm{mm} /$ month) is the precipitation summed over the previous 30 days and $K=2.15 \mathrm{~mm} /$ month (the halfsaturation constant of the hyperbolic relationship of soil respiration with monthly precipitation), taken from Reichstein et al. (2003). The parameter $P_{0}$ is fixed to the approximate global value of $1.55 \mathrm{~mm} /$ month $(95 \%$ confidence interval: $[0.2,2.5])$ taken from Reichstein et al. (2003).

The a priori values of the parameters $\left(R_{0}, R_{\mathrm{LAI}}, K, E\right)$ are modified from the soil-respiration values of Reichstein et al. (2003) assuming that soil respiration accounts for $60 \%$ of ecosystem respiration. $E$ corresponds to $Q_{10}=1.47$ (Reichstein et al., 2003), which is a relatively low value, reflecting the fact that the present model is formulated in terms of air temperature (rather than the more usual soil temperature) which has more temporal variability than the temperature of the soil and most of the plant tissue that drive ecosystem respiration. The leaf area index dependence (replaced by fAPAR) describes the status of vegetation structure. Therefore, the model introduced here accounts for both climate and biological variations in soil respiration (Reichstein et al., 2003), while still being much simpler than process-based models.

\subsection{Filtering and aggregation}

To test the performance of SDPRM, the estimated fluxes from the model are shown on a variety of spatial and temporal scales. The main focus of the analysis is the interannual variability and the monthly mean seasonal cycle of the flux estimates.

To obtain the interannual variability, the estimated fluxes are filtered by subtracting the mean seasonal cycle and most variations faster than 1 year (filter with Gaussian spectral weights, as in Rödenbeck (2005)). This filter essentially retains annual averages. Likewise for the spatial resolution of the results, the estimated fluxes are integrated either into three latitudinal bands $\left(90^{\circ} \mathrm{S}-20^{\circ} \mathrm{S}, 20^{\circ} \mathrm{S}-20^{\circ} \mathrm{N}\right.$ and $20^{\circ} \mathrm{N}-$ $90^{\circ} \mathrm{N}$ ) or into the land regions as defined in the TransCom 3 project (Gurney et al., 2002) (see Fig. 3).

\section{Results and discussion}

\section{1 fAPAR}

Figure 4 shows the time series of the full-temporal variability and the running annual average (box-car filter) of the calculated fAPAR from GIMMS NDVI data set. The time series is aggregated over three latitudinal bands (for a map of the regions see Fig. 3). In the Northern Hemisphere, fAPAR has striking seasonal changes, i.e., small values in winter and high values in summer, reflecting the vegetation phenology of the region. Over the tropics, the interannual variability has more variations because the major drivers associated with 
(A) Three latitudinal zones

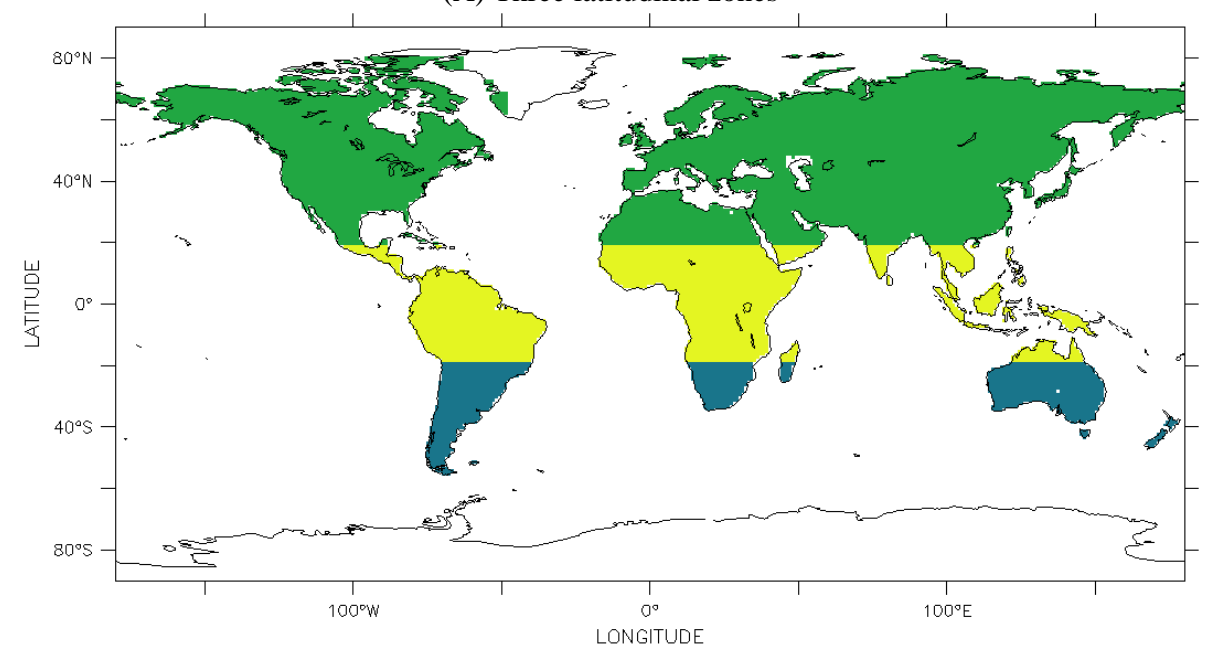

(B): TransCom regions

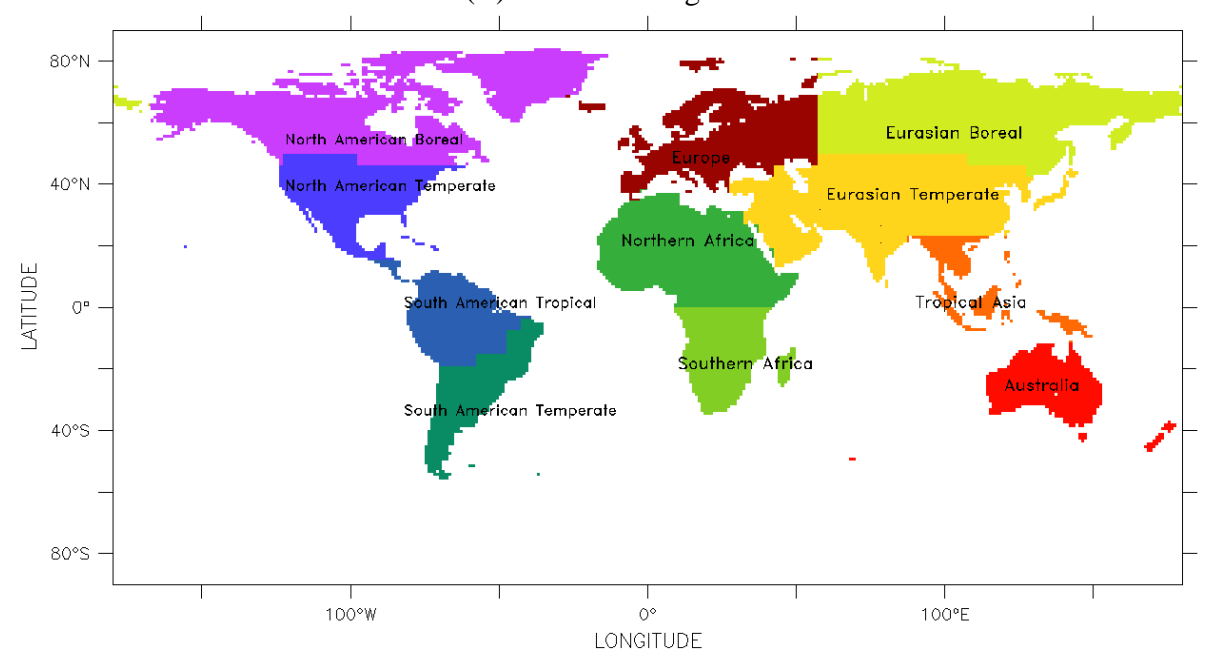

Fig. 3. Map of the land regions over which the estimated fluxes are integrated to obtain time series. (A) land regions for three latitudinal bands defined as $\left(90^{\circ} \mathrm{S}-20^{\circ} \mathrm{S}, 20^{\circ} \mathrm{S}-20^{\circ} \mathrm{N}\right.$ and $\left.20^{\circ} \mathrm{N}-90^{\circ} \mathrm{N}\right)$. (B) land regions as defined in the TransCom3 project (Gurney et al., 2002).

the growing season (e.g., precipitation, temperature) have high variations. Also, the natural variability in atmospheric aerosols and column water vapor may have created surfaceindependent variations in the GIMMS NDVI record (Tucker et al., 2005). As a consequence, fAPAR inherited these variations that may not be caused by vegetation variation. In June 1991, a major volcanic eruption occurred (the Pinatubo eruption), injecting large quantities of aerosols into the earth's stratosphere. These aerosols and subsequent cooling can explain the decline in the interannual variability of fAPAR during the period from 1991 to 1993 over the tropics. This indicates that GIMMS NDVI data may be problematic in certain regions/periods and should be used with caution (Hall et al., 2006; Nemani et al., 2003) (a detailed analysis is beyond the scope of this paper). Consequently, by using satellite-derived fAPAR data set to drive the photosynthesis model, GPP esti- mates will be affected by a substantial variability in fAPAR that is not related to actual changes in the vegetation function (see Sect. 3.2.1).

\subsection{Model comparison}

In an inversion calculation as the envisaged use of the model, a priori fluxes already need to be structurally compatible with reality, as otherwise it is not possible to find realistic results by changing parameter Kaminski and Heimann (2001). Therefore, several analysis are performed to test the performance of the model and its ability to produce suitable a priori fields for the inversion. The estimates of NEE $\left(R_{\text {eco }}-\right.$ GPP) from SDPRM are compared with the land flux inferred from the atmospheric measurements of $\mathrm{CO}_{2}$ using updated results from Rödenbeck (2005) (called here STD-inv). This is in order to assess to which extent the a priori land fluxes from 
Table 3. Climatic contributions to the interannual variability of GPP and $R_{\text {eco }}$ over different land regions. The contribution was calculated using Eq. (15) and 16.

\begin{tabular}{lccccc}
\hline & \multicolumn{3}{c}{ GPP } & \multicolumn{2}{c}{$R_{\text {eco }}$} \\
\hline Land regions & VPD & Radiation & Temperature & Precipitation & Temperature \\
\hline Land total & 0.43 & 0.39 & 0.18 & 0.32 & 0.68 \\
Northern Hemisphere & 0.47 & 0.10 & 0.43 & 0.13 & 0.87 \\
Tropical land & 0.44 & 0.56 & 0.00 & 0.51 & 0.49 \\
Southern Hemisphere & 0.89 & 0.09 & 0.02 & 0.83 & 0.17 \\
North American bor. & 0.17 & 0.05 & 0.77 & 0.02 & 0.98 \\
North American temp. & 0.77 & 0.14 & 0.09 & 0.40 & 0.60 \\
South American trop. & 0.46 & 0.53 & 0.00 & 0.74 & 0.26 \\
South American temp. & 0.76 & 0.21 & 0.03 & 0.68 & 0.32 \\
Europe & 0.56 & 0.17 & 0.27 & 0.14 & 0.86 \\
Northern Africa & 0.58 & 0.42 & 0.00 & 0.62 & 0.38 \\
Southern Africa & 0.76 & 0.24 & 0.00 & 0.91 & 0.09 \\
Eurasian boreal & 0.28 & 0.10 & 0.63 & 0.10 & 0.90 \\
Eurasian temperate & 0.53 & 0.34 & 0.13 & 0.45 & 0.55 \\
Tropical Asia & 0.11 & 0.89 & 0.00 & 0.55 & 0.45 \\
Australia & 0.91 & 0.09 & 0.01 & 0.88 & 0.12 \\
\hline
\end{tabular}

SDPRM are consistent in structure to the variability inferred from the atmospheric measurements.

In addition, the estimated carbon cycle components (GPP, $R_{\text {eco }}$ ) from SDPRM are compared with the results of the BIOME-BGCv1 process-based model (Trusilova and Churkina, 2008) as an independent means for validation. This is to substantiate that SDPRM formulations make sense also in a process understanding. BIOME-BGCv1 is based on the core of the BIOME-BGC version 4.1.1 (Thornton et al., 2005 [accessed: Dec. 2010]) point-based model. BIOME-BGC prognostically simulates the states and fluxes of carbon, nitrogen, and water within the vegetation, litter, and soil components of a terrestrial ecosystem (Appendix D). The BIOME-BGCv1 model uses the NCEP/NCAR meteorological fields as driving data.

\subsubsection{CfAPAR vs. VfAPAR}

To remove the spurious variation in fAPAR due to the residual contamination effects, NEE alternately is estimated by assuming constant vegetation (i.e., 1982-2006 mean seasonal cycle of fAPAR) (hereafter referred to as SDPRM-CfAPAR). Then NEE estimates from SDPRM-CfAPAR are compared with NEE driven by the full-temporal variability of fAPAR time series (referred to as SDPRM-VfAPAR). In both runs, we use varying climate (daily NCEP/NCAR reanalysis data).

Figure 5 shows the comparison between the anomaly (deviation from the mean of 1982-2006) of IAV of NEE from SDPRM-CFAPAR and SDPRM-VfAPAR and the estimated land flux from STD-inv. The fossil fuel emissions is subtracted for STD-inv line. In STD-inv, the yearly totals and geographical distribution of the fossil fuel emissions are taken from the Emission Database for Global Atmospheric Research (EDGAR) (Source: European Commission, Joint Research Centre (JRC)/Netherlands Environmental Assessment Agency (PBL). Emission Database for Global Atmospheric Research (EDGAR), release version 4.0. http://edgar.jrc.ec. europa.eu, 2009). In Fig. 5, IAV of NEE from SDPRMVfAPAR has some striking peaks, in particular over the tropics, during the period 1991-1993 compared to STD-inv. This can be explained by the variability in fAPAR (inherited from GIMMS NDVI) during the period from 1991 to 1993 over the tropical region due to Pinatubo eruption, which injected large quantities of aerosols into the stratosphere. These aerosols, along with smoke from biomass burning and dust from soil erosion and other factors, can introduce a significant variability in AVHRR NDVI record (Tucker et al., 2005) and hence fAPAR data set. Also, volcanic aerosols can reduce the photosynthetic activity by reducing the amount of sunlight reaching vegetations (Oliveira et al., 2007; Krakauer and Randerson, 2003). The statistical analysis shows low correlation coefficient between the global total of NEE from SDPRM-VfAPAR and the global land fluxes from STD-inv $(r=0.31)$.

On the other hand, IAV of NEE from SDPRM-CfAPAR can capture a substantial fraction of IAV of land fluxes as inferred from the atmospheric information using STD-inv. The correlation coefficient between the two land estimates is higher $(r=0.53)$ compared to SDPRM-VfAPAR, and therefore SDPRM-CfAPAR is used in the following sections. The better agreement between SDPRM-CfAPAR and STD-inv indicates that most of the interannual variability of NEE is dominated by the climate signal (Mercado et al., 2009). 
(A)

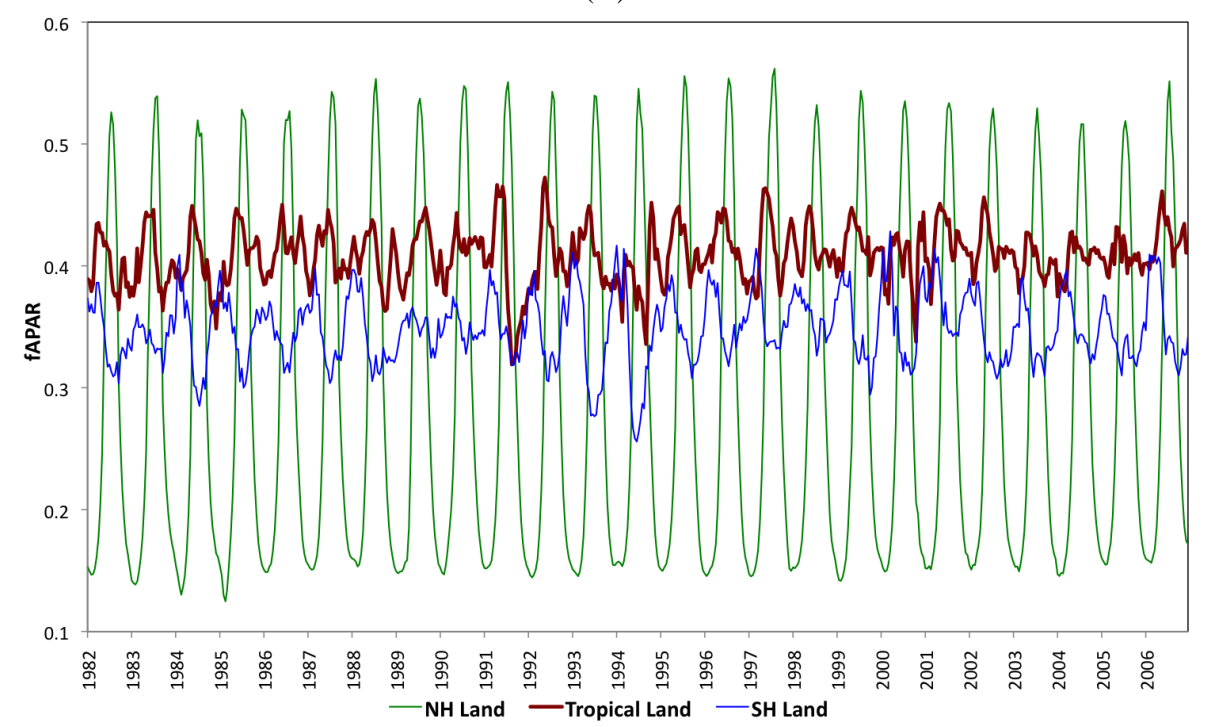

(B)

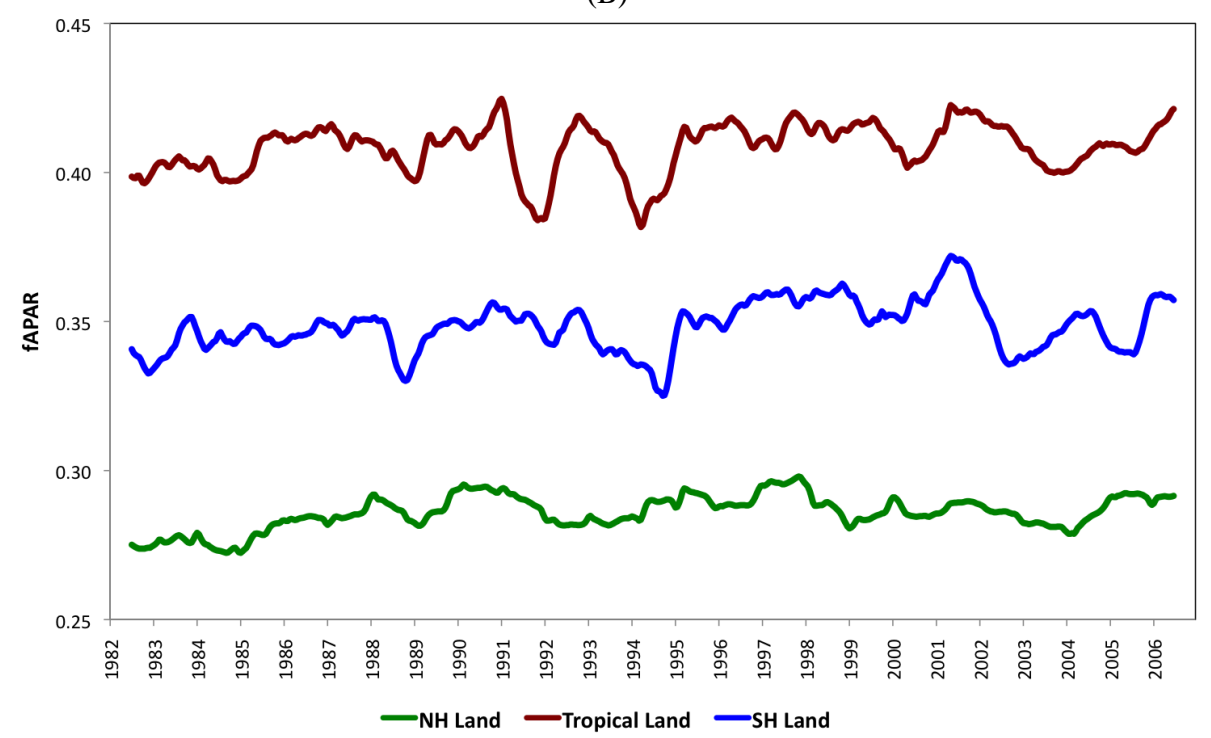

Fig. 4. Integrated fAPAR time series calculated from GIMMS NDVI across three latitudinal bands: (A) time series of the full-temporal variability of fAPAR, (B) time series of the running annual average (box-car filter) of fAPAR. For a map of the regions see Fig. 3.

\subsubsection{SDPRM vs. BIOME-BGCv1}

The comparison between the calculated NEE from SDPRMCfAPAR and NEE simulated by BIOME-BGCv1 is illustrated in Fig. 6 for 3 latitudinal bands (see Fig. 3). The land flux estimates from STD-inv is shown in the same figure. It shows that IAV of NEE from SDPRM-CfAPAR (Fig. 6B) has a similar pattern compared to the NEE simulated by the BIOME-BGCv1 model, in particular over the tropics (temporal correlation coefficient $r=0.63$ ). Similarly, Fig. 7b shows the same comparison but for TransCom 3 land regions (see Fig. 3). SDPRM-CfAPAR and BIOME-BGCv1 agree in many temporal features over most of the regions. In contrast, STD-inv has higher IAV of the land flux as well as a different pattern compared to SDPRM-CfAPAR and BIOMEBGCv1. Due to the scarcity of the atmospheric $\mathrm{CO}_{2}$ observations, the results of STD-inv might not be well constrained over smaller regions. Also, missing processes (e.g., fire) in the biosphere models can also be the reason for the discrepancies between the flux variability shown in Fig. $7 \mathrm{~b}$.

The monthly mean seasonal cycle of the flux estimates from the three models are shown in Fig. 6a and Fig. 7a. The general phase of the seasonal cycle of NEE from SDPRMCfAPAR is similar to the seasonal cycle of the land flux 

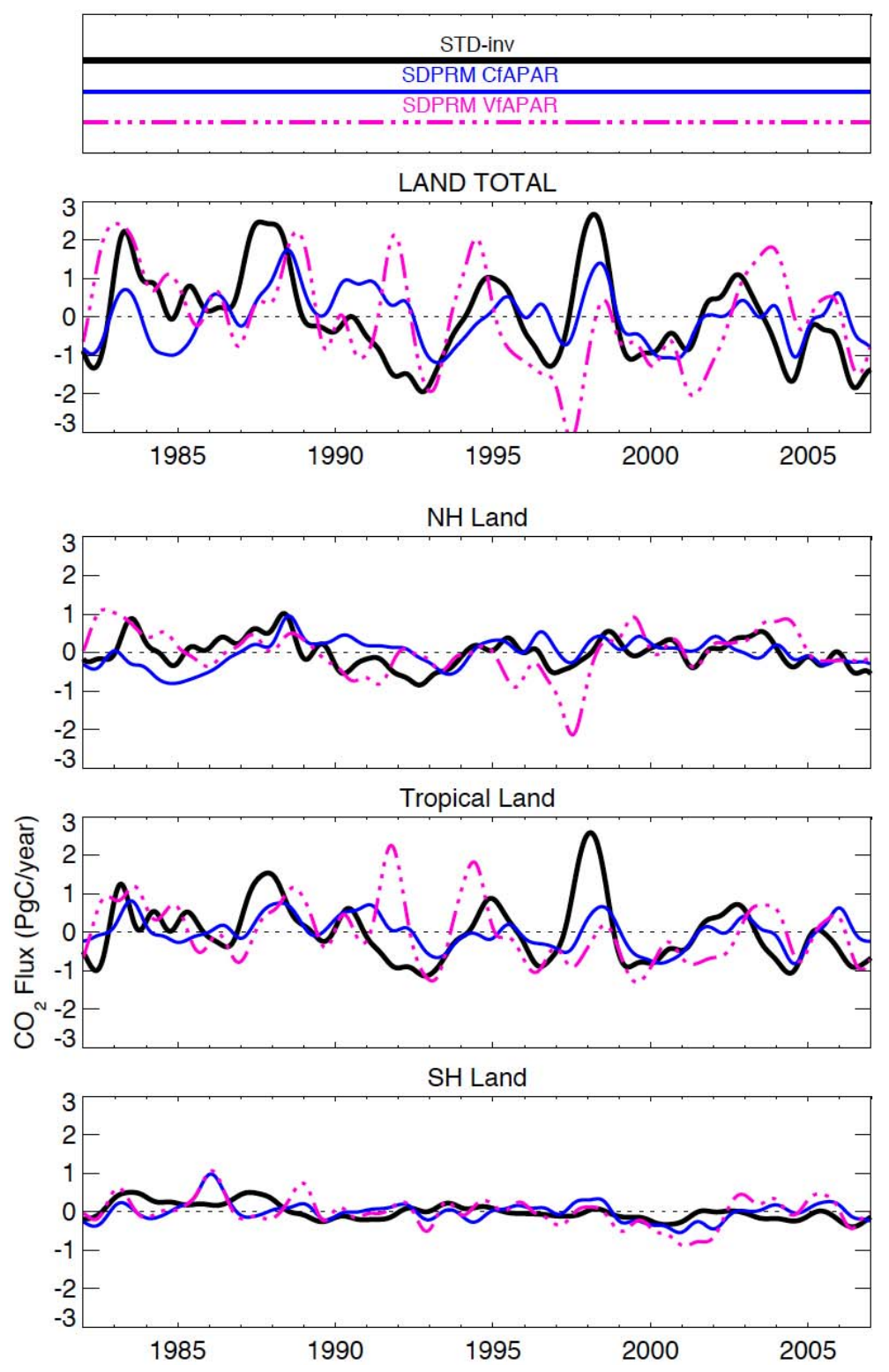

Fig. 5. The comparison between the anomaly (deviation from the mean of 1982-2006) of the IAV of the estimated NEE from SDPRMCfAPAR (using the mean seasonal cycle of fAPAR) [Blue] and SDPRM-VfAPAR (using the full variability of fAPAR) [Magenta dashed] and the total land flux estimated by STD-inv [Black]. The time series are integrated over three latitudinal bands (for the map of the regions see Fig. 3) and de-seasonalized and filtered for interannual variability (as in Rödenbeck (2005)). The fossil fuel emissions have been subtracted for STD-inv line.

estimated from STD-inv over northern hemispheric land $(\mathrm{NH})$, though the amplitude is higher in SDPRM-CfAPAR. In terms of phasing, however, SDPRM-CfAPAR agrees much better to the atmospheric information (STD-inv) compared to the more sophisticated model (BIOME-BGCv1), which leads STD-inv by about 2 months in various regions, especially in the northern high-latitudes. In addition to NEE, we also compare the carbon cycle components (GPP and $\left.R_{\text {eco }}\right)$ from SDPRM-CfAPAR with the results from BIOME-
BGCv1, for both the monthly mean seasonal cycle and IAV (Fig. 8 and Fig. 9). The comparisons show that GPP and $R_{\text {eco }}$ from SDPRM-CfAPAR agree well with those from BIOMEBGCv1 although both models are using different algorithms for calculating GPP and $R_{\text {eco }}$. In the MOD17 algorithm used in SDPRM for GPP calculation, VPD is the only variable directly related to environmental water stress, while both VPD and soil water content are used for water stress calculations in BIOME-BGCv1. 
(A) Monthly mean seasonal cycle
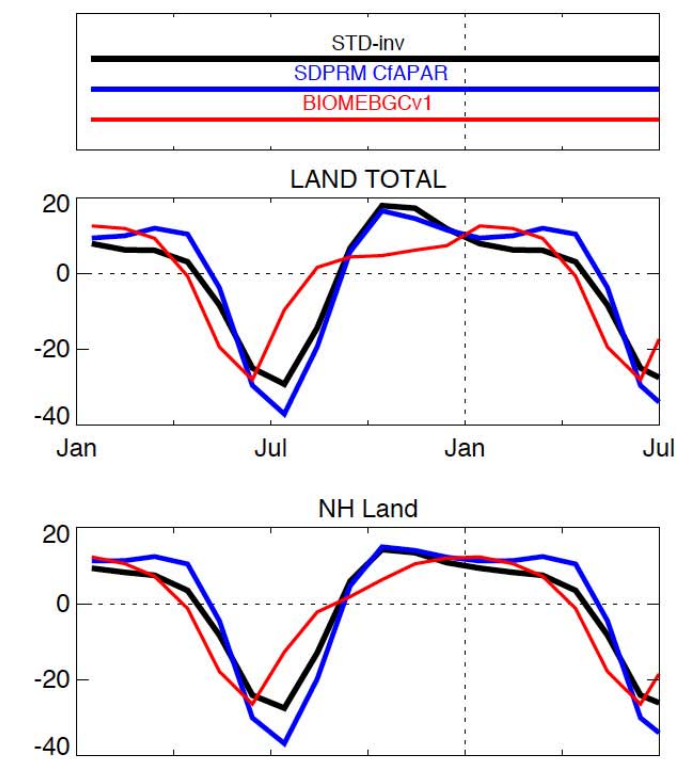

Tropical Land

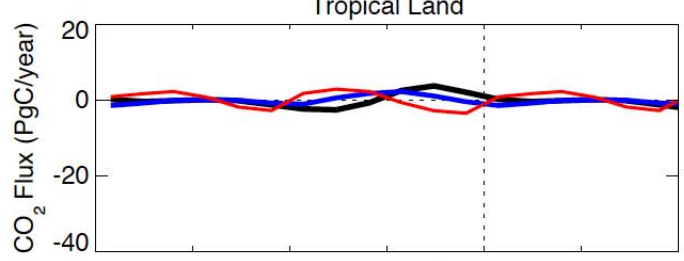

SH Land

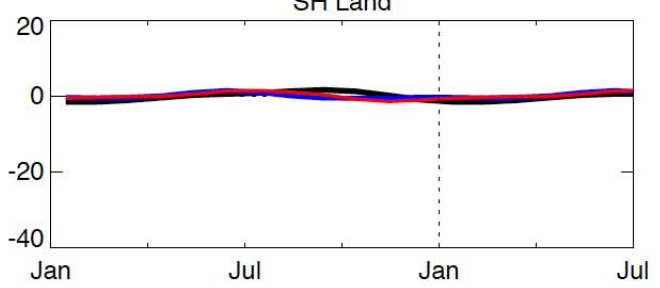

(B) Interannual Variability

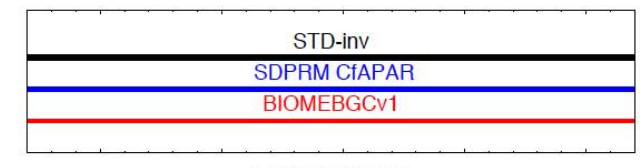

LAND TOTAL
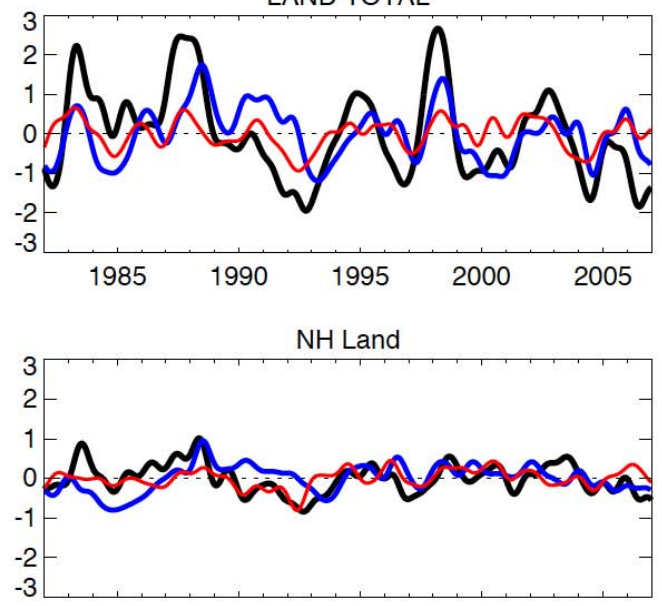

Tropical Land

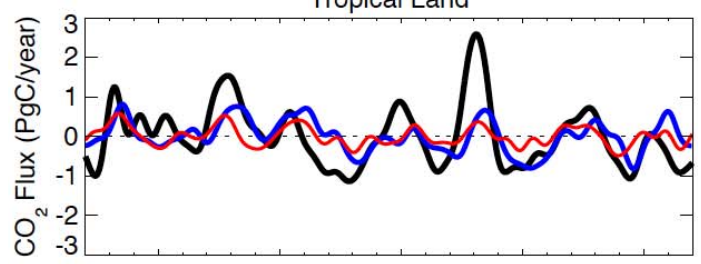

SH Land

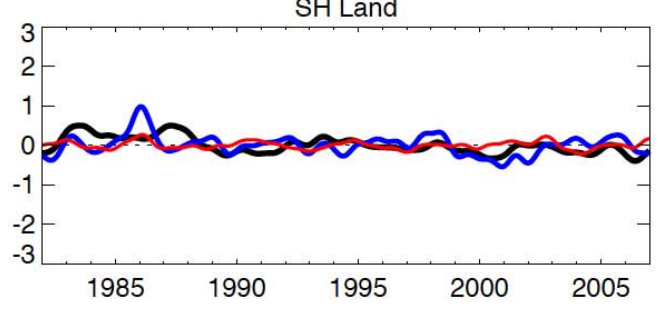

Fig. 6. The comparison between NEE estimates from SDPRM-CfAPAR [Blue], BIOME-BGCv1 [Red], and the land flux estimated by STD-inv [Black] for the monthly mean seasonal cycle (A) and for the interannual variability (B). The time series are integrated over three latitudinal bands (for the map of the regions see Fig. 3) and de-seasonalized and filtered for interannual variability (as in Rödenbeck (2005)). The fossil fuel emissions have been subtracted from STD-inv line.

In Fig. 9a, the monthly mean seasonal cycles of $R_{\text {eco }}$ from SDPRM and BIOME-BGCv1 are presented. As mentioned earlier, the parameters and the structure of the respiration model in SDPRM were chosen from the soil-respiration model of Reichstein et al. (2003) which was calibrated using field measurements from Europe and North America. Also, $R_{\text {eco }}$ is calculated in SDPRM using only climate drivers and the maximum fAPAR and independent of GPP. But in the real world, $R_{\text {eco }}$ is strongly connected to GPP on seasonal timescales (Mahecha et al., 2010; Migliavacca et al., 2011). This might explain why SDPRM is underestimating the amplitude of the seasonal cycle of $R_{\text {eco }}$ compared to BIOME-
BGCv1, in particular over Europe, North American temperate and boreal, and Eurasian boreal (Fig. 9a).

\subsubsection{Summary}

Though a comprehensive evaluation of SDPRM against independent data sources is a significant challenge (e.g., due to the contrast between the point-scale nature of the groundbased flux measurements (on the order of a few square kilometers or less (Baldocchi, 2003)) and the spatial resolution of SDPRM ( $4^{\circ}$ latitude $\times 5^{\circ}$ longitude), we conclude from the comparison between SDPRM-CFAPAR, BIOME-BGCv1 and the STDinv, which SDPRM-CfAPAR - despite its simple 
(A) Monthly mean seasonal cycle
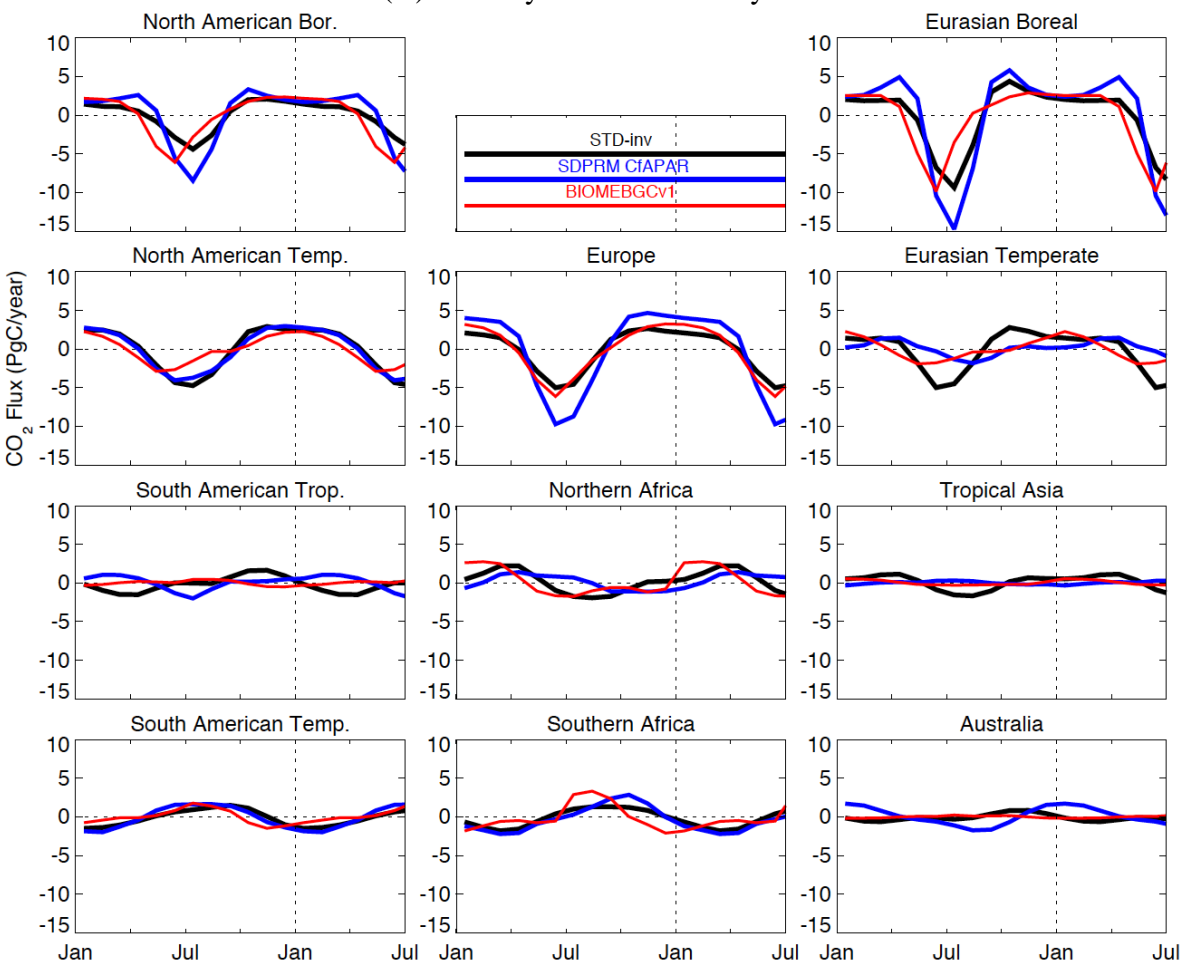

(B) Interannual Variability (IAV)
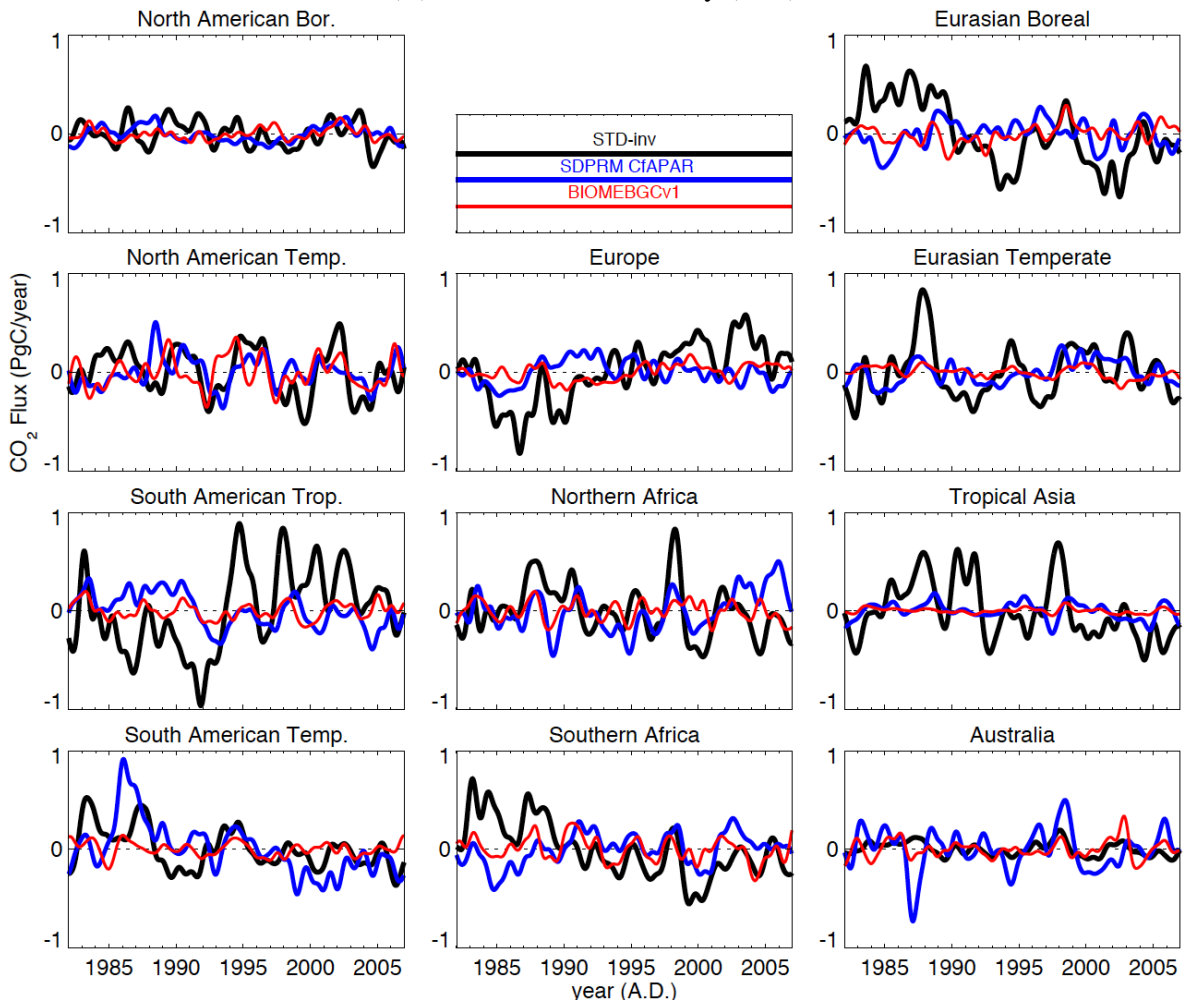

Fig. 7. The comparison between the estimated NEE from SDPRM-CfAPAR [Blue], BIOME-BGCv1 [Red] , and the land flux estimated by STD-inv [Black] for the monthly mean seasonal cycle (A) and for the interannual variability (B). The time series are integrated over 11 land regions (for the map of the regions see Fig. 3) and de-seasonalized and filtered for interannual variability (as in Rödenbeck (2005)). The fossil fuel emissions have been subtracted from STD-inv line. 
(A) Monthly mean seasonal cycle
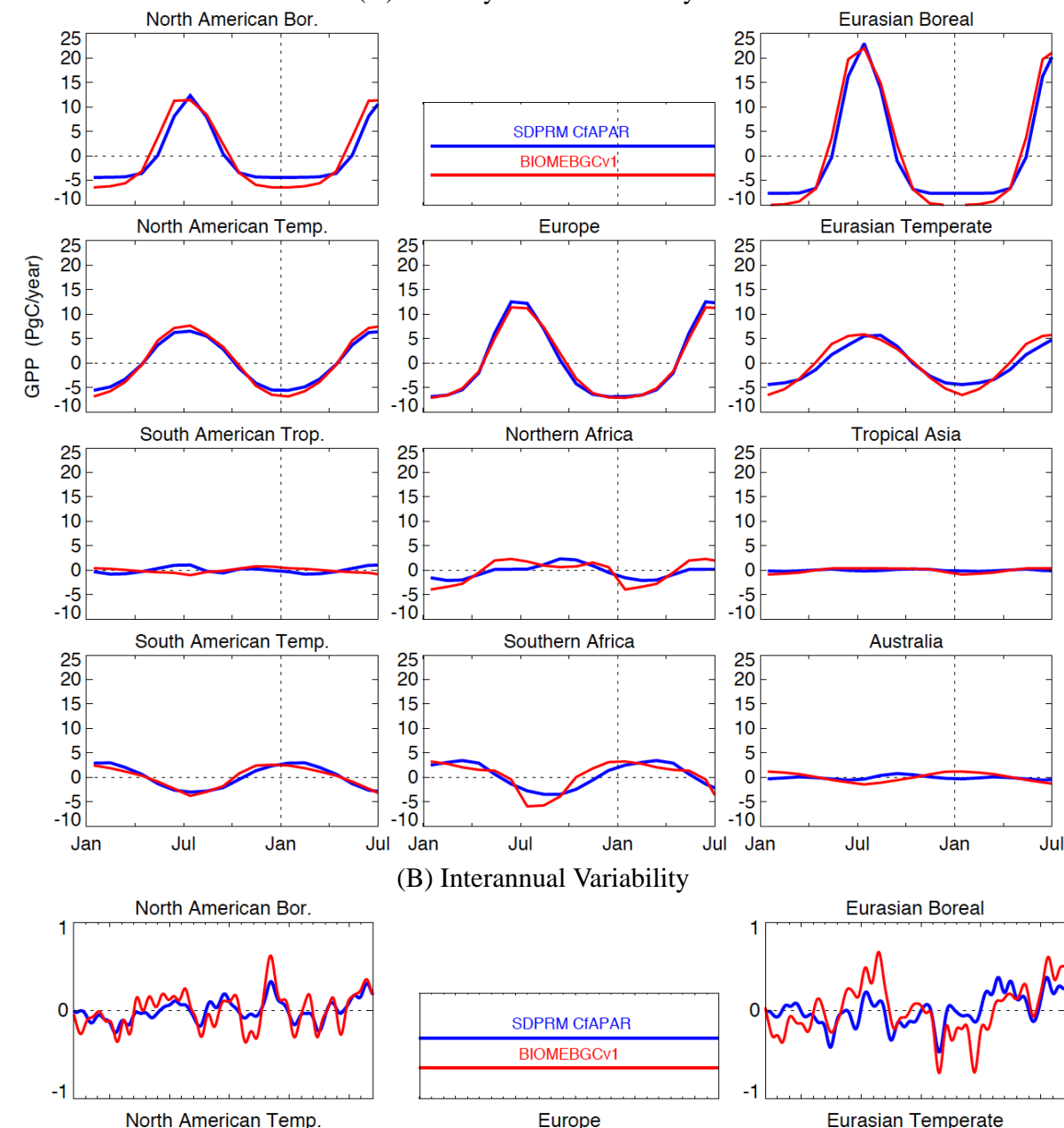

(B) Interannual Variability
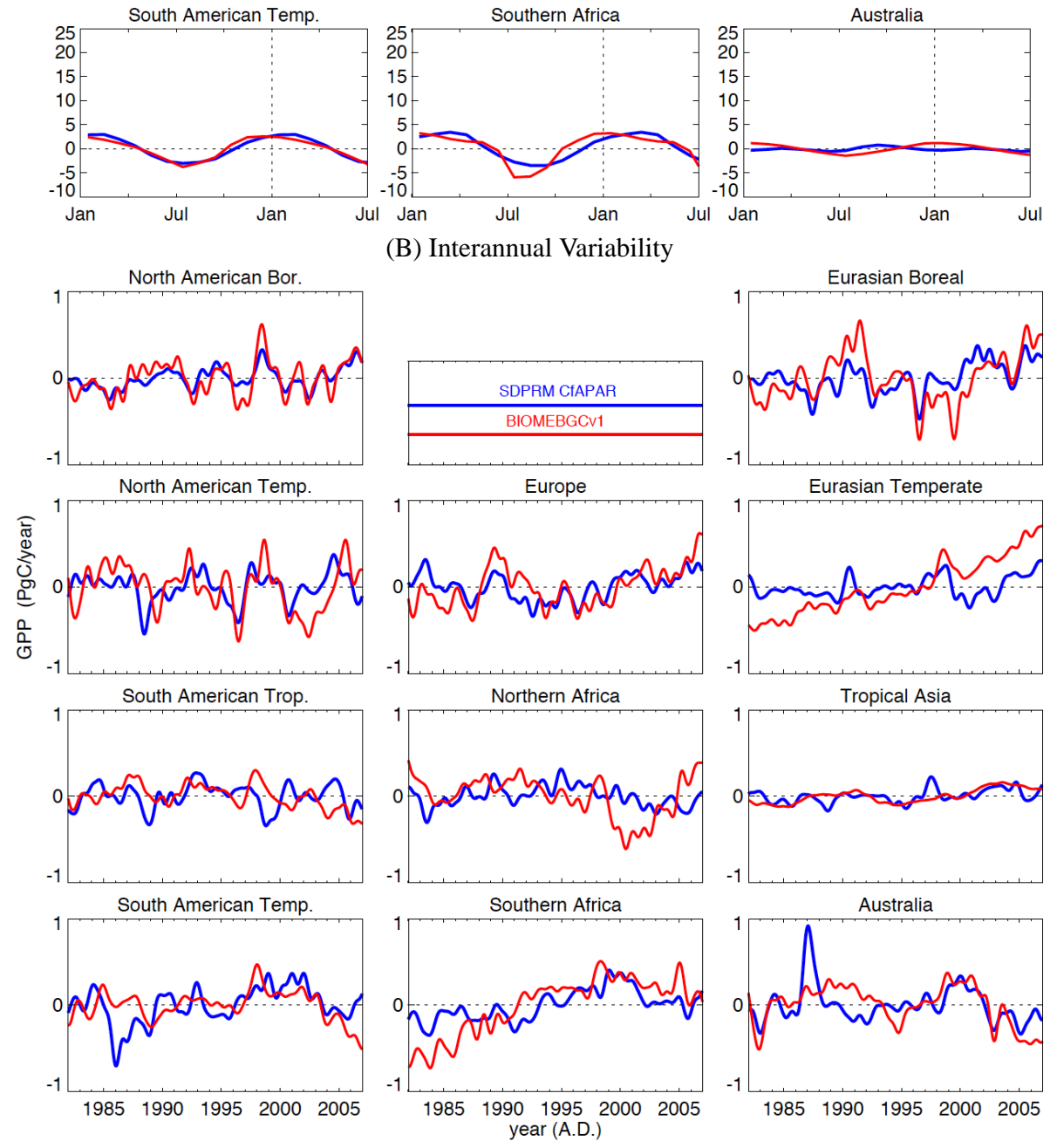

Fig. 8. The comparison between the estimated GPP from SDPRM-CfAPAR [Blue], and from BIOME-BGCv1 [Red] for the monthly mean seasonal cycle (A) and for the interannual variability (B). The time series are integrated over 11 land regions (for the map of the regions see Fig. 3) and de-seasonalized and filtered for interannual variability (as in Rödenbeck (2005)). 

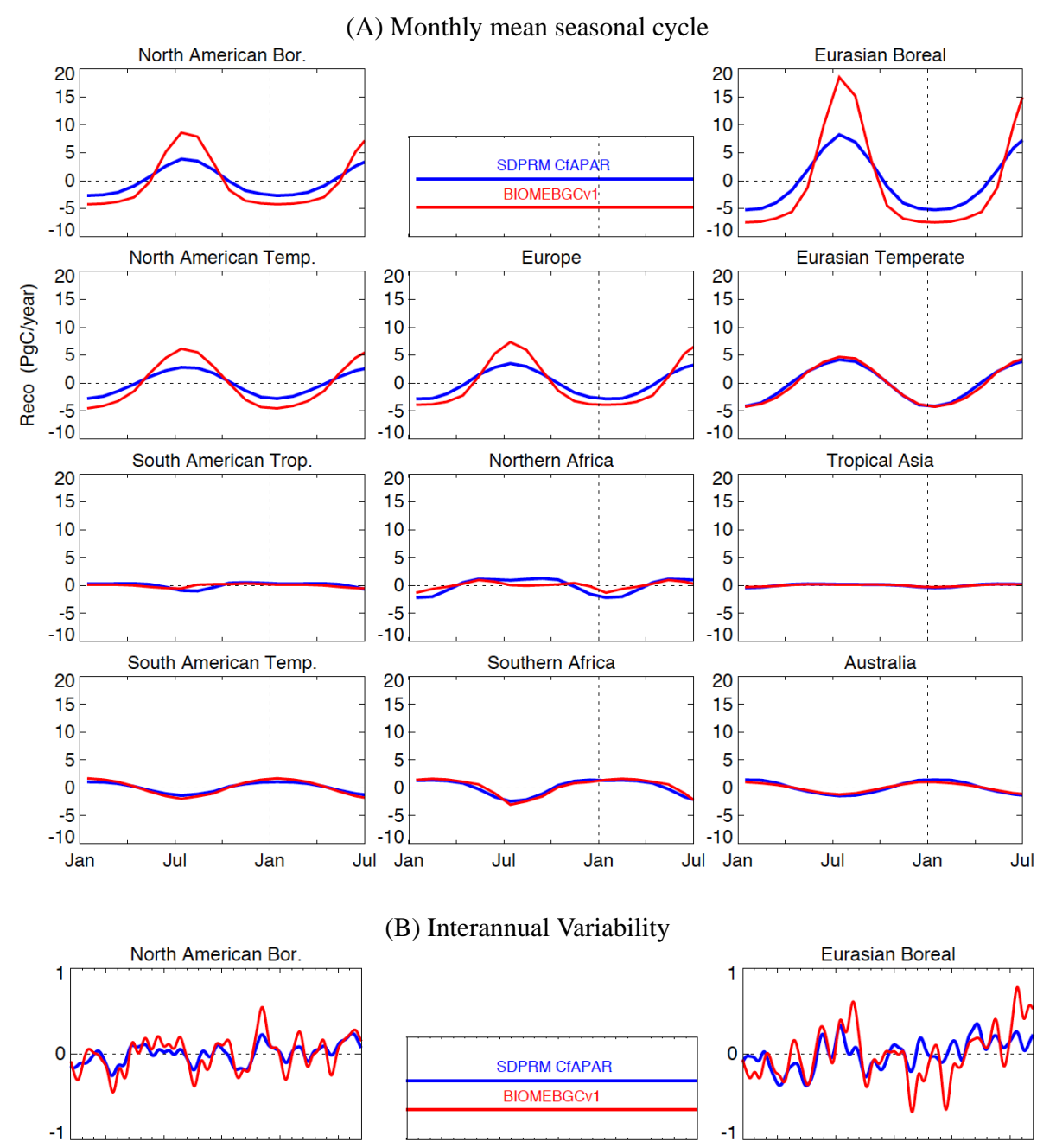

(B) Interannual Variability
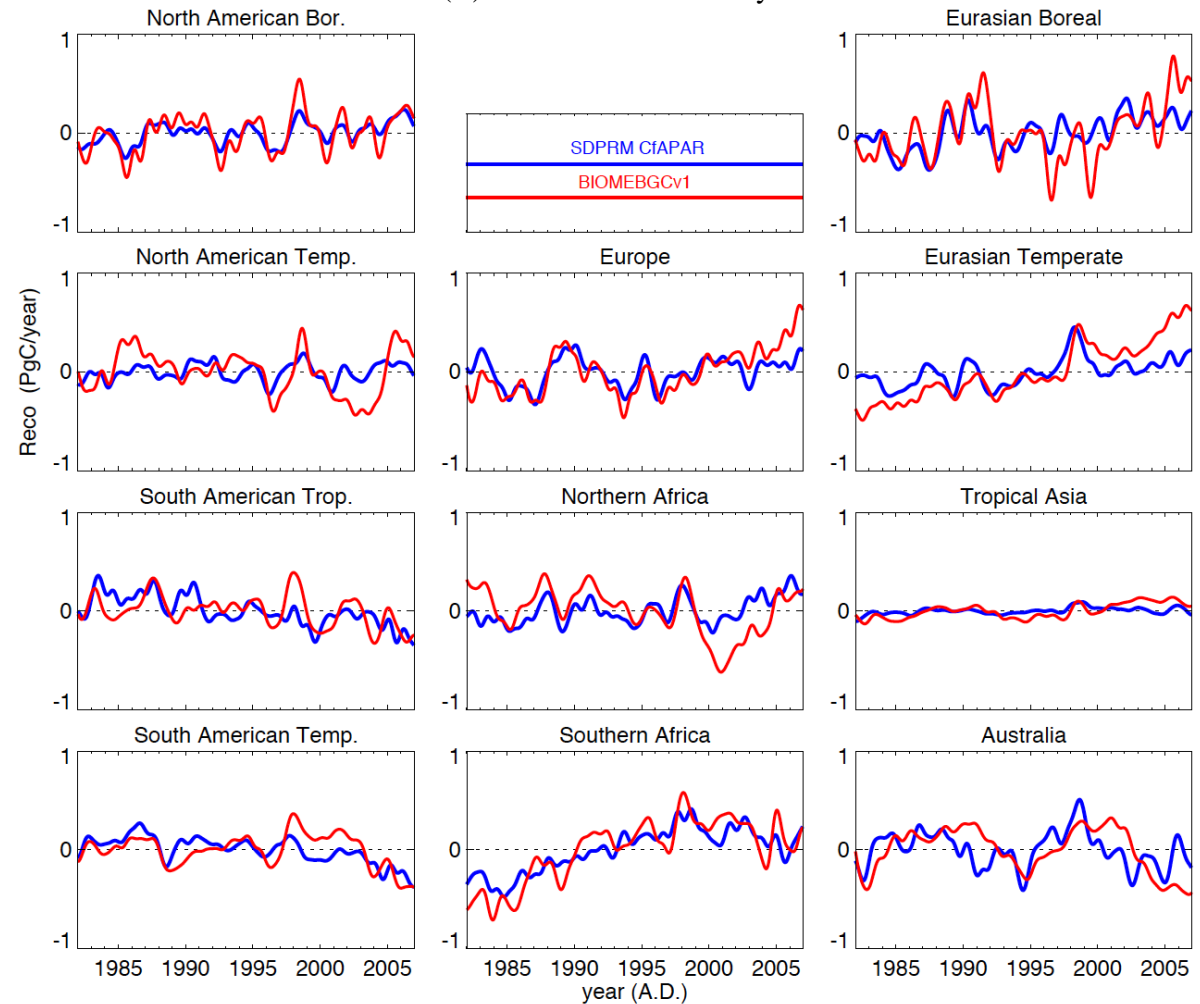

Fig. 9. The comparison between the estimated $R_{\text {eco }}$ from SDPRM-CfAPAR [Blue], and from BIOME-BGCv1 [Red] for the monthly mean seasonal cycle $(\mathbf{A})$ and for the interannual variability $(\mathbf{B})$. The time series are integrated over 11 land regions (for the map of the regions see Fig. 3) and de-seasonalized and filtered for interannual variability (as in Rödenbeck (2005)). 
(A) Temperature contribution to the IAV of GPP
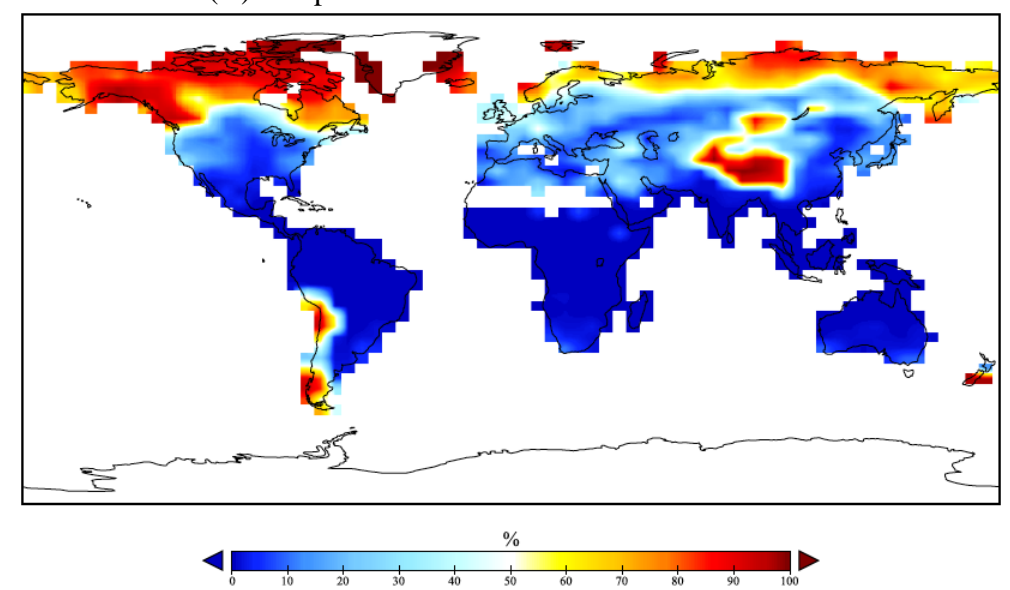

(B) VPD contribution to the IAV of GPP
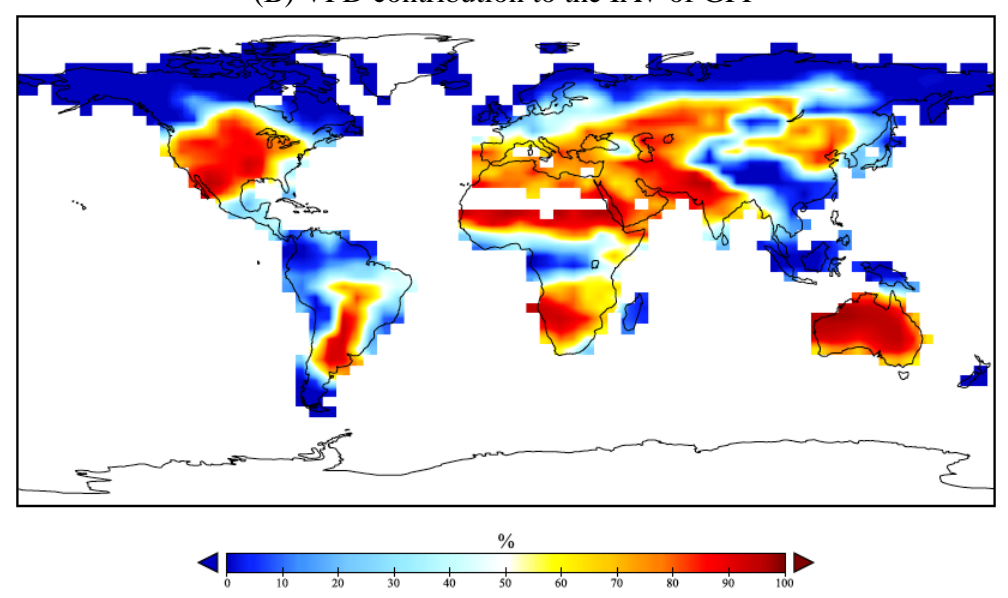

(C) Radiation contribution to the IAV of GPP

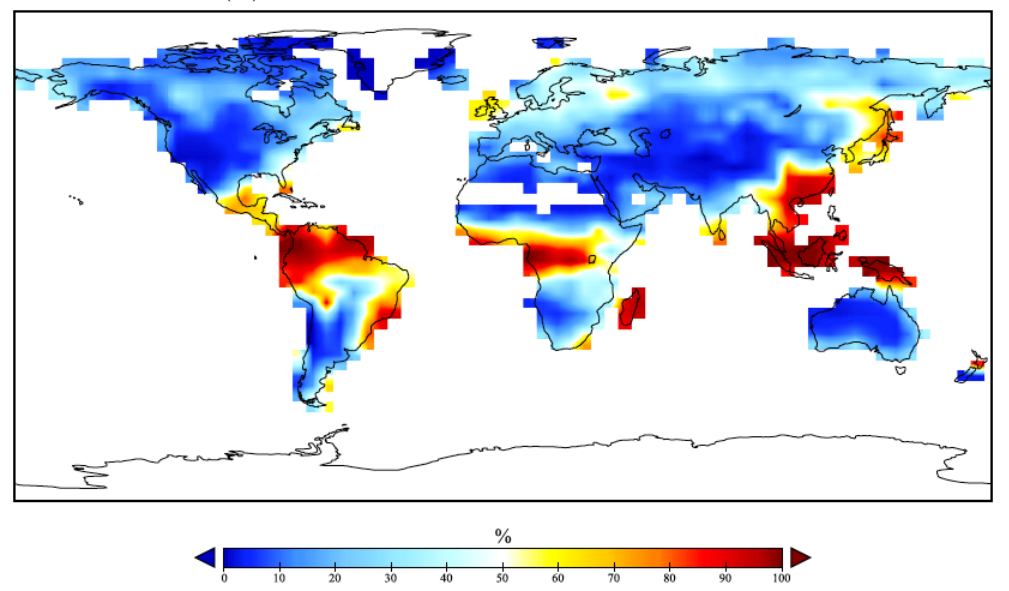

Fig. 10. The global distribution of the relative contribution of each climate variable ((A) temperature: high values indicate LOW temperature is limiting, (B) vapor pressure deficit (VPD): high value indicate HIGH VPD is limiting, and (C) radiation: high value indicate high LOW radiation is limiting) to the interannual variability (IAV) of GPP. 
(A) Temperature contribution to the IAV of $R_{\mathrm{eco}}$

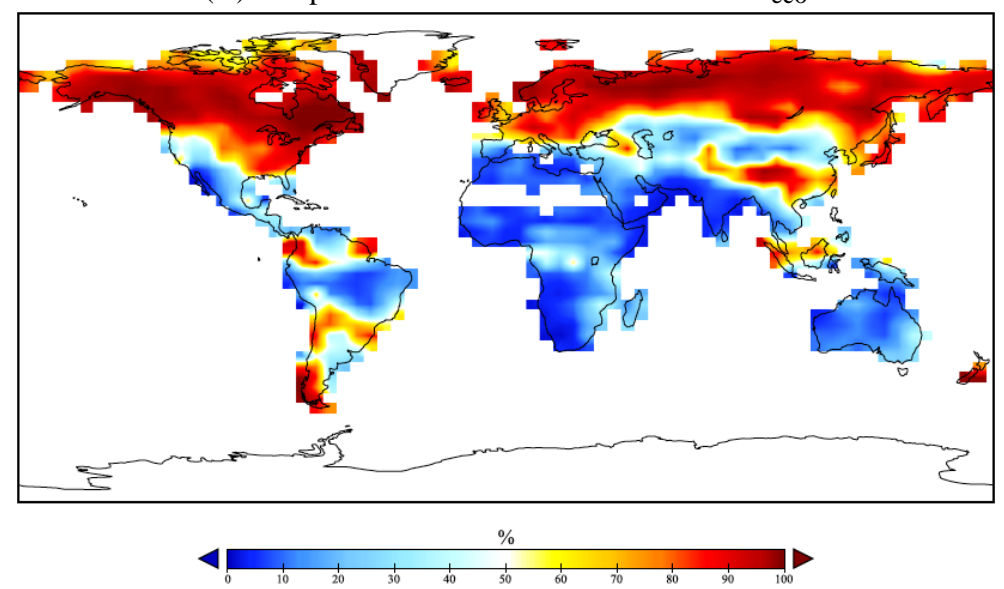

(B) Precipitation contribution to the IAV of $R_{\text {eco }}$

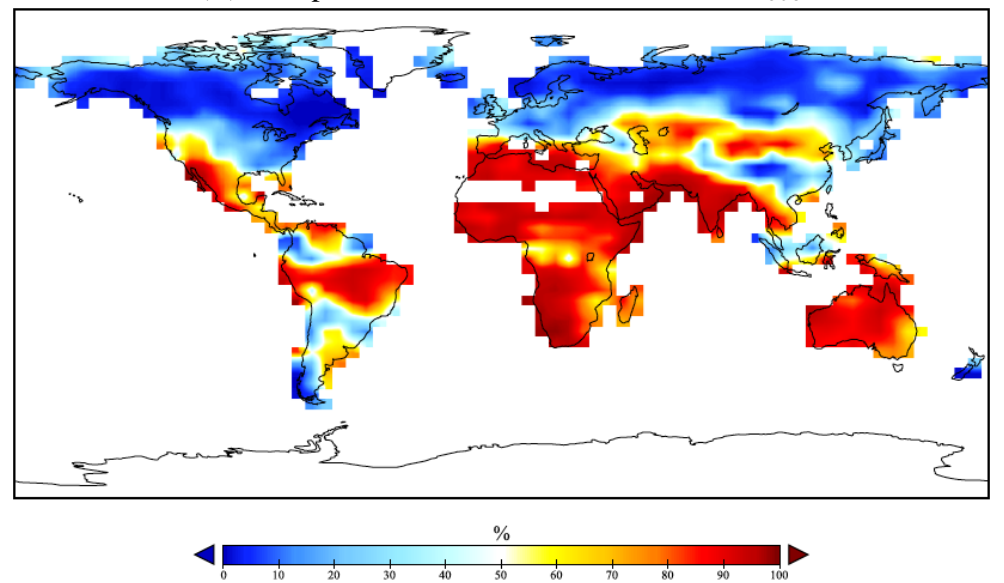

Fig. 11. The global distribution of the relative contribution of each climate variable ((A) temperature: high values indicate LOW temperature is limiting, (B) precipitation: high values indicate LOW precipitation is limiting) to the interannual variability (IAV) of $R_{\text {eco. }}$.

structure - is capable of reproducing flux patterns compatible to the ones inferred from the atmospheric measurements or inferred based on process understanding. This is important in light of its intended use.

\subsection{Climate limitations}

Understanding responses of GPP and $R_{\text {eco }}$ to climate controls is crucial to understand terrestrial carbon cycle and climate feedbacks in the future. Many studies have shown strong relationships between the annual climate (means) and ecosystem productivity (e.g., Stephenson (1990); Churkina and Running (1998); Valentini et al. (2000); Nemani et al. (2003); Running et al. (2004); Wang et al. (2011) and others). They also show that any small variation in the annual climate can have a significant impact on the plant growth and biome stability. Thus, it seems reasonable to use the year-toyear variation (IAV) of climate variables as indicators of the ecosystem productivity limitation. Fundamentally, a statistical model such as SDPRM only reflects the statistical influ- ence of different factors but it does not necessarily reflect a causal relationship. Nevertheless, SDPRM should still incorporate the most important biological factors. Therefore, it is worthwhile investigating whether SDPRM shows the climate sensitivity of $R_{\text {eco }}$ and GPP as presented by mechanistic models.

Here, we present an analysis to assess the importance of the climatic variables (used to drive SDPRM) in limiting the interannual variations of GPP and $R_{\text {eco. }}$. The effects of the interannual variation in each climate variable are investigated by removing the IAV of the other climate variables (using only the mean seasonal cycle for the period 1982 to 2006, applied repeatedly every year) and using constant vegetation (mean seasonal cycle fAPAR as in run SDPRMCfAPAR). In the case of GPP, simulations allow for the isolation of the effects of daily minimum temperature (GT: minimum temperature only varying and other climate drivers constant (mean seasonal cycle)), vapor pressure deficit (GV: VPD only varying and other climate drivers constant), and 
downward shortwave radiation (GS: radiation only varying and other climate drivers constant). In the case of $R_{\text {eco }}$, simulations allow isolation of the effects daily temperature (RT: daily temperature only varying and other climate drivers constant), and precipitation (RP: precipitation only varying and other climate drivers constant). Then, the relative contribution of each independent climate variable on GPP and $R_{\text {eco }}$ estimates (1982-2006) is calculated with a logic similar to the one suggested by Ichii et al. (2005) which can be expressed as

$$
\begin{aligned}
\mathrm{GC}_{i} & =\frac{\sigma_{G_{i}}^{2}}{\sigma_{\mathrm{GT}}^{2}+\sigma_{\mathrm{GV}}^{2}+\sigma_{G S}^{2}} \\
R C_{i} & =\frac{\sigma_{R_{i}}^{2}}{\sigma_{\mathrm{RT}}^{2}+\sigma_{\mathrm{RP}}^{2}}
\end{aligned}
$$

where $\mathrm{GC}_{i}$ and $\mathrm{RC}_{i}$ are the proportional contribution of $\sigma_{G_{i}}^{2}$ and $\sigma_{R_{i}}^{2}$, the variance of the anomalies of the interannual variability of GPP and $R_{\text {eco }}$, respectively, for each of the sensitivity cases $\left(G_{i}=\mathrm{GT}, \mathrm{GV}\right.$, or GS, while $R_{i}=\mathrm{RT}$ or TP), to the sum of the variance of all of the sensitivity cases. High/low $\mathrm{GC}_{i}$ or $\mathrm{RC}_{i}$ indicates large/small contribution of the climate driver $i$ on overall variance.

Based on the calculations of the squared correlation coefficient $\left(R^{2}\right)$, it is found that GPP anomalies in the default run (SDPRM-CfAPAR - constant vegetation and all climate variables are varying) were mostly explained by the sum of all sensitivity runs (one variable is varying and the others are constants) $\left(R^{2}=0.98\right)$. The same is found for $R_{\text {eco. }}$. This indicates that the main effects are essentially additive and that extensive non-linear interactions do not exist. Therefore, non-linear responses of GPP or $R_{\text {eco }}$ to interactions among climate variables (e.g., simultaneous changes in temperature and radiation) are not investigated.

As mentioned, SDPRM equations reflect the statistical influence of different variables but do not justify the underlying mechanisms of the influence. The quantitative conclusions of the climate sensitivity analysis are therefore uncertain and should be drawn with caution.

\subsubsection{Climate Controls on GPP}

Based on Eq. (15), Fig. 10 shows the global distribution of the relative contribution of each climate variable (temperature, vapor pressure deficit, and radiation) to the interanuual variability of GPP. The results are also summarized in Table 3 for different eco-regions. The following features can be observed:

Temperature: In the high latitudes, temperature is clearly the primary control on GPP (Fig. 10a), in particular over the North American boreal forest and Eurasian boreal forest (77\% and $63 \%$, respectively) and to a lesser extent over Europe and the Eurasian temperate forest $(27 \%$ and $13 \%$, respectively, see Table 3). On average, temperature limits GPP over the Northern Hemisphere by almost $43 \%$. Despite it is consistent with the governing equations of the model, this can be explained by the fact that at low temperatures the enzymes responsible for photosynthesis are inhibited. Thus, very low mean annual temperatures limit plant productivity as in the case of tundra and boreal forests in northern latitudes. The tropics and the southern hemispheric areas are not limited by low temperature (less than $2 \%$ ). Similar findings are presented by Nemani et al. (2003), who investigated vegetation responses to climatic changes by analyzing 18 years (1982 to 1999) of both climatic data and satellite observations of vegetation activity using BIOME-BGC model. According to their study, cold winter temperatures limit highlatitude Eurasian vegetation, while tropical areas are never limited by low temperatures.

Vapor pressure deficit: As mentioned earlier, in the MOD17 algorithm for calculating GPP, VPD is the only variable directly related to environmental water stress. Therefore, VPD is used as an indicator of environment water stress. It is clear from Fig. 10b that VPD is a dominant control on GPP over large areas of the globe where water is severely limited, mainly Australia, North and South American temperate forest, southern Africa, southern Europe, and the Sahara desert (see Table 3). This is also consistent with the finding of Nemani et al. (2003) that water availability most strongly limits vegetation growth over $40 \%$ of the earth's vegetated surface, and vapor pressure deficit (VPD) is a limiting factor of vegetation growth in water-limited ecosystems of Australia, Africa, and the Indian subcontinent.

Radiation: Radiation is another important limiting factor on GPP, as it represents the energy source of photosynthesis. Interannual variations in radiation result from interannual variations in cloud cover. According to that, we can see in Fig. 10c that radiation limits GPP by almost $56 \%$ over the area covered most of the year by cloud (tropical regions). But radiation is also a limiting control on GPP, over some areas in the Northern Hemisphere, such as Eurasian temperate, Europe, and North American temperate, though to a lesser degree. Nemani et al. (2003) also found that radiation is a limiting factor in western Europe and the equatorial tropics regions.

\subsubsection{Climate Controls on $\boldsymbol{R}_{\text {eco }}$}

Similarly, based on Eq. (16), Fig. 11 shows the global distribution of the relative contribution of each climate variable (temperature, precipitation) to the interannual variability of $R_{\text {eco. }}$. Additionally, the calculated values based on Eq. (16) for different regions are shown in Table 3 . The results of the relative contribution of each climate factor to $R_{\text {eco }}$ are summarized as follows:

Temperature: Similar to GPP, temperature partially determines the respiration rates of vegetation. Consequently, plants growing in cold regions are usually less productive. Thus, $R_{\text {eco }}$ of plants from cold regions is primarily limited 
by temperature. Figure 11 shows that clearly, where temperature limits $R_{\text {eco }}$ by almost $87 \%$ over the Northern Hemisphere and by a lower rate over tropical regions (49\%). The results are consistent with the regional studies in particular over the boreal ecosystems (e.g., Wang et al. (2011)).

Precipitation: Precipitation is a dominant control on $R_{\text {eco }}$ over large areas of the globe where water is severely limiting, in particular the tropics and southern hemispheric regions (Fig. 11).

\section{Discussion and conclusions}

In this Technical Note, we presented and evaluated the Simple Diagnostic Photosynthesis and Respiration Model (SDPRM). The model estimates 3-hourly values of GPP and daily values of ecosystem respiration $\left(R_{\mathrm{eco}}\right)$. The spatial resolution of the model is $4^{\circ}$ latitude $\times 5^{\circ}$ longitude. The model is driven by climate data from NCEP/NCAR and satellitederived fAPAR data.

Given the coarse spatial resolution of SDPRM, groundbased flux measurements cannot be used to validate the results directly. Therefore, to test the performance of the model, we compared the carbon flux components (NEE, GPP, and $R_{\text {eco }}$ ) with two different approaches for estimating the land fluxes, (1) the process-understanding approach presented by the BIOME-BGCv1 model, and (2) the atmospheric $\mathrm{CO}_{2}$ inversion in which the land fluxes are inferred from the atmospheric information. It is found that, by using climatological fAPAR and varying climate data, SDPRMCfAPAR is capable of reproducing flux patterns (IAV and the mean seasonal cycle integrated over several land regions) comparable to the ones inferred from the atmospheric measurements or simulated based on process understanding. This indicates that in SDPRM a sizable fraction of the interannual variability of NEE can be represented by variations in climate (not vegetation changes).

Furthermore, the sensitivities of GPP and $R_{\text {eco }}$ to the driving climate variables are investigated by estimating the relative contribution of individual climate variables to the interannual variability of GPP and $R_{\text {eco }}$. Based on the analysis, low temperature controls the IAV of GPP mainly over highlatitude Eurasian vegetation. Over the tropics, radiation is the main limiting factor of the IAV of GPP. VPD controls the IAV of GPP in water-limited ecosystems. Temperature controls the IAV of $R_{\text {eco }}$ over large areas of the globe, in particular over northern hemispheric regions. Also, precipitation controls the IAV of $R_{\text {eco }}$ over large areas of the globe, in particular over the tropics and southern hemispheric regions. The results of this analysis are consistent with previous studies that use a more sophisticated process-based model (i.e., Nemani et al. (2003)). It indicates that the simple SDPRM formulations still make mechanistic sense.

SDPRM has the advantage that it uses few driving variables and few adjustable parameters, and thus is flexible to be optimized in an inversion. However, the simplification of our model structure can lead to considerable uncertainty in regional flux estimates. For example, the model uses constant parameters that are specified globally or for only 7 PFTs. But in the real world, these parameters are controlled by details of species composition, site history including changes in land use, etc., and thus can result in substantial variability in regional flux estimates. Also, deficiencies in the spatial resolution and the accuracy of land cover representation can lead to considerable uncertainty in the flux estimates. The current classification may have to be revised based on future diagnostics. However, the present choice does not seem a priori unreasonable to us, because the aggregation of pixels into the same class only means that the response of the local flux to the local climate is forced to be the same. The deficiency in the satellite-derived fAPAR data is a limitation as well and can produce large errors in the estimated fluxes for certain regions/times. As mentioned earlier, the dependency of respiration on GPP might need to be included as an additional driver of $R_{\text {eco }}$ (Mahecha et al., 2010; Migliavacca et al., 2011). The biases in NCEP/NCAR reanalyses also can introduce substantial error into GPP and $R_{\text {eco }}$ estimates. The other limitation of SDPRM is the missing of important processes (e.g., fire, land use changes, etc.).

The model will replace, in a subsequent paper, the simple statistical flux representation of the inversion algorithm presented by Rödenbeck (2005) to optimize key parameters of the model in order to fit the observed $\mathrm{CO}_{2}$ concentrations. Optimizing model parameters instead of the fluxes themselves can provide flux estimates that are structurally consistent with the process parametrizations used. Different parameter configurations can be tested to determine which parameters are globally valid and which have to be spatially explicit. Due to the missing processes in SDPRM, we expect that the model will not be able to fit the observed concentration completely; however, the residual fluxes corresponding to the residual between the modeled and the observed concentration can then be used to investigate the contribution of some of the missing processes, as will be discussed in more detail in the subsequent paper.

\section{Appendix A}

\section{fAPAR}

fAPAR is calculated following the approach described in Goward and Huemmrich (1992) and Sellers et al. (1996a) and further adapted by Los et al. (2000). Two linear equations between fAPAR and NDVI are described, referred to as the fAPAR $_{\mathrm{NDVI}}$ and fAPAR $\mathrm{SR}_{\mathrm{SR}}$ models. In the fAPAR $_{\mathrm{NDVI}}$ model, maximum and minimum NDVI values for each vegetation type are related to maximum and minimum fAPAR 
according to

$$
\begin{aligned}
\mathrm{fAPAR}_{\mathrm{NDVI}} & =\frac{\left(\mathrm{NDVI}-\mathrm{NDVI}_{\text {min }}\right)\left(\mathrm{fAPAR}_{\text {range }}\right)}{\mathrm{NDVI}_{\text {range }}} \\
& +\mathrm{fAPAR}_{\text {min }},
\end{aligned}
$$

where $\quad \mathrm{NDVI}_{\text {range }}=\mathrm{NDVI}_{\max }-\mathrm{NDVI}_{\min } \quad$ corresponds to the difference between the $98^{\text {th }}$ and $2^{\text {nd }}$ percentiles of the NDVI frequency distribution estimated per PFT (see Table A1). The parameter fAPAR range equals $\mathrm{fAPAR}_{\text {max }}-\mathrm{fAPAR}_{\min }=0.95-0.01$. In the $\mathrm{fAPAR}_{\mathrm{SR}}$ model, fAPAR is linearly related to the simple ratio (SR) which can be expressed as a transformation of NDVI:

$\mathrm{SR}=\frac{1+\mathrm{NDVI}}{1-\mathrm{NDVI}}$

$\mathrm{fAPAR}_{\mathrm{SR}}=\frac{\left(\mathrm{SR}-\mathrm{SR}_{\text {min }}\right)\left(\mathrm{fAPAR}_{\text {range }}\right)}{\mathrm{SR}_{\text {range }}}+\mathrm{fAPAR}_{\text {min }}$,

where $\mathrm{SR}_{\text {range }}=\mathrm{SR}_{\max }-\mathrm{SR}_{\min }$ corresponds to the difference between the 98th and 2nd percentiles of the SR frequency distribution. Based on the study of Los et al. (2000), in fAPAR $_{\text {NDVI }}$ relationships, NDVI values was not corrected for the effect of the atmosphere (i.e., water vapor and aerosols) that causes significant overestimates of fAPAR. In fAPAR $_{S R}$ relationships, atmospheric effects are partially accounted for by the statistical selection of NDVI values, but still it produces significant underestimates of fAPAR. According to Los et al. (2000), an intermediate model, calculating the average fAPAR of the fAPAR ${ }_{N D V I}$ and fAPAR $_{S R}$ models, performed better by giving the smallest bias in fAPAR estimates in comparison to the ground-measured fAPAR. Accordingly, fAPAR is calculated using the following relationship:

$\mathrm{fAPAR}=\frac{\mathrm{fAPAR}_{\mathrm{SR}}+\mathrm{fAPAR}_{\mathrm{NDVI}}}{2}$.

These calculations are done on a pixel basis with $8 \mathrm{~km} \times 8$ $\mathrm{km}$ spatial resolution. After that, the fAPAR data have been aggregated to a spatial resolution of $4^{\circ}$ latitude $\times 5^{\circ}$ longitude. Then, a separate data set, fAPAR $\mathrm{PFT}_{\mathrm{P}}$, is created for each PFT.

\section{Appendix B}

\section{Incident radiation}

Incident radiation $I(x, y, t)$ is calculated from the downward shortwave radiation $I_{\mathrm{SW}}(x, y, t)$ from NCEP meteorological reanalysis, which contains both the seasonal and synoptic variability, while the diurnal variation is only coarsely represented in the 6-hourly fields. Therefore, incident radiation is calculated as

$I(x, y, t)=j(x, y, t) \cdot I_{0}(x, y, t)$,
Table A1. Lower (2nd) and upper (98th) NDVI percentiles estimated per PFT.

\begin{tabular}{lcc}
\hline PFT(class) & NDVI $_{\min }$ & NDVI $_{\max }$ \\
\hline ENF (1) & 0 & 0.83 \\
EBF (2) & 0 & 0.90 \\
DxF (3) & 0 & 0.85 \\
SHR (4) & 0 & 0.75 \\
SAV (5) & 0 & 0.81 \\
GRS (6) & 0 & 0.74 \\
CRO (7) & 0 & 0.80 \\
\hline
\end{tabular}

where $I_{0}(x, y, t)$, from the purely geometrical clear-sky radiation, is

$$
\begin{aligned}
I_{0}(x, y, t) & =\max \left(0, \sin (y) \cdot \sin \left(x_{\Delta}\right)\right. \\
& \left.+\cos (y) \cdot \cos \left(x_{\Delta}\right) \cdot \cos \left(x_{h}\right)\right)
\end{aligned}
$$

with

$x_{h}=360^{\circ} r_{\text {day }}(t)+x-180^{\circ}$

$x_{\Delta}=-23.4^{\circ} \cdot \cos \left(360^{\circ} r_{\text {year }}(t)+10^{\circ}\right)$,

where $r_{\text {day }}(t)$ and $r_{\text {year }}(t)$ give the fractions of the day (since 00 UTC) and of the year (since 1 January) at time $t$, and $x$ and $y$ are taken to represent longitude and latitude. The cloud factor $j(x, y, t)$ is obtained by the following equation at the 6-hourly meteorological intervals, and linearly interpolated in between.

$j(x, y, t)=\frac{I_{\mathrm{SW}}(x, y, t)}{I_{0}(x, y, t)}$

\section{Appendix C}

\section{Vapor Pressure deficit (VPD)}

VPD $(x, y, t)$ (difference between actual partial pressure of water vapor and saturation water vapor pressure in $\mathrm{Pa}$ ) is calculated as a daytime mean from specific humidity $q$ $(\mathrm{kg} \mathrm{kg} 6-1)$, sea level pressure $p(\mathrm{~Pa}) \approx 101300 \mathrm{~Pa}$, air temperature at $2 \mathrm{~m}$ height $T\left({ }^{\circ} \mathrm{C}\right)$, and the ratio $\kappa=0.62197$ of the molar masses of water vs. air as

$\mathrm{VPD}=611 \cdot \exp \left(\frac{17.26938818 \cdot \mathrm{T}}{237.3+\mathrm{T}}\right)-\frac{\mathrm{q} \cdot \mathrm{p}}{\kappa-\mathrm{q}(\kappa-1)}$

The daytime average was done using $I_{0}(x, y, t)$ from Eq. (B2) as weighting, and applying a triangular filter to dediurnalize. 


\section{Appendix D}

\section{BIOME-BGCv1}

In BIOME-BGCv1, the total ecosystem respiration $\left(R_{\text {eco }}\right)$ includes three components: maintenance respiration (MR), growth respiration (GR), and heterotrophic respiration (HR). MR of each plant compartment is computed as a function of compartment nitrogen content and temperature. GR is calculated on the basis of construction costs by plant compartment. Different construction costs are applied to woody and non-woody plant tissues. HR includes decomposition of both litter and soil. It is related to their chemical composition (cellulose, lignin, and humus), to their carbon to nitrogen ratios, to soil mineral nitrogen availability and to soil moisture and temperature. The gross photosynthetic production (GPP) is calculated based on absorbed photosynthetically active radiation, atmospheric carbon dioxide concentration, air temperature, vapor pressure deficit, soil water content, atmospheric nitrogen deposition, the leaf area index, and available nitrogen content in soil. For the comparison, the BIOME-BGCv1 results were aggregated from $0.5^{\circ} \times 0.5^{\circ}$ to the spatial resolution of $4^{\circ} \times 5^{\circ}$ as in SDPRM and STD-inv. Further details about the structure of BIOME-BGCv1 are described in Trusilova et al. (2009).

Acknowledgements. The authors would like to thank the Max Planck Society for providing funding and facilities, Martin Jung for providing us with SYNMAP data, Miguel D. Mahecha for fruitful discussions about statistical analyses, Sönke Zaehle for his helpful comments. We would also like to thank Global Land Cover Facility, University of Maryland for making NDVI GIMMS data available for free.

The service charges for this open access publication have been covered by the Max Planck Society.

Edited by: G. Wohlfahrt

\section{References}

Baker, D. F., Doney, S. C., and Schimel, D. S.: Variational data assimilation for atmospheric $\mathrm{CO}_{2}$, Tellus B, 58, 359-365, 2006.

Baldocchi, D., Reichstein, M., Papale, D., Koteen, L., Vargas, R., Agarwal, D., and Cook, R.: The role of trace gas flux networks in the biogeosciences, EOS, Trans. Am. Geophys. Union, 93, 217218, 2012.

Baldocchi, D. D.: Assessing ecosystem carbon balance: problems and prospects of the eddy covariance technique, Global Change Biol., 9, 479-492, 2003.

Bousquet, P., Peylin, P., Ciais, P., Le Quéré, C., Friedlingstein, P., and Tans, P. P.: Regional changes in carbon dioxide fluxes of land and oceans since 1980, Science, 290, 1342-1346, 2000.

Canadell, J. G., Mooney, H. A., Baldocchi, D. D., Berry, J. A., Ehleringer, J. R., Field, C. B., Gower, S. T., Hollinger, D. Y.,
Hunt, J. E., Jackson, R. B., Running, S. W., Shaver, G. R., Steffen, W., Trumbore, S. E., Valentini, R., and Bond, B. Y.: Carbon Metabolism of the Terrestrial Biosphere: A Multitechnique Approach for Improved Understanding, Ecosystems, 3, 115-130, 2000.

Churkina, G. and Running, S.: Contrasting climatic controls on the estimated productivity of global terrestrial biomes, Ecosystems, 1, 206-215, 1998.

D’Arrigo, R. D., Malmstrom, C. M., Jacoby, G. C., Los, S. O., and Bunker, D. E.: Correlation between maximum latewood density of annual tree rings and NDVI based estimates of forest productivity, Int. J. Remote Sens., 21, 2329-2336, 2000.

Davenport, M. L. and Nicholson, S. E.: On the Relation between Rainfall and the Normalized Difference Vegetation Index for Diverse Vegetation Types in East Africa, Int. J. Remote Sens., 14, 2369-2389 doi:10.1080/01431169308954042, 1993.

Denning, A. S., Collatz, G. J., Zhang, C. G., Randall, D. A., Berry, J. A., Sellers, P. J., Colello, G. D., and Dazlich, D. A.: Simulations of terrestrial carbon metabolism and atmospheric $\mathrm{CO}_{2}$ in a general circulation model. 1. Surface carbon fluxes, Tellus B, 48, 521-542, 1996.

Enting, I., Trudinger, C. M., and Francey, R. J.: A synthesis inversion of the concentration and $\delta^{13} \mathrm{C}$ of atmospheric $\mathrm{CO}_{2}$, Tellus, 47B, 35-52, 1995.

Friend, A. D., Arneth, A., Kiang, N. Y., Lomas, M., Ogée, J., Rödenbeckk, C., Running, S. W., Santaren, J.-D., Sitch, S., Viovy, N., Woodward, F. I., and Zaehle, S.: FLUXNET and modelling the global carbon cycle, Global Change Biol., 13, 610-633, 2007.

Goward, S. N. and Huemmrich, K. F.: Vegetation canopy PAR absorbtance and the normalized difference vegetation index: An assessment using the SAIL model, Remote Sens. Environ., 39, 119-140, 1992.

Gurney, K. R., Law, R. M., Denning, A. S., Rayner, P. J., Baker, D., Bousquet, P., Bruhwiler, L., Chen, Y.-H., Ciais, P., Fan, S., Fung, I. Y., Gloor, M., Heimann, M., Higuchi, K., John, J., Maki, T., Maksyutov, S., Masarie, K., Peylin, P., Prather, M., Pak, B. C., Randerson, J., Sarmiento, J., Taguchi, S., Takahashi, T., and Yuen, C.-W.: Towards robust regional estimates of $\mathrm{CO}_{2}$ sources and sinks using atmospheric transport models, Nature, 415, 626630, 2002.

Hall, F., Masek, J. G., and Collatz, G. J.: Evaluation of ISLSCP Initiative II FASIR and GIMMS NDVI products and implications for carbon cycle science, J. Geophys. Res., 111, 15 pp., doi:10.1029/2006JD007438, 2006.

Heimann, M., Esser, G., Haxeltine, A., Kaduk, J., Kicklighter, D. W., Knorr, W., Kohlmaier, G. H., McGuire, A. D., Melillo, J., Moore III, B., Otto, R. D., Prentice, I. C., Sauf, W., Schloss, A., Sitch, S., Wittenberg, U., and Würth, G.: Evaluation of terrestrial carbon cycle models through simulations of the seasonal cycle of atmospheric $\mathrm{CO}_{2}$ : First results of a model intercomparison study, Glob. Biogeochem. Cy., 12, 1-24, 1998.

Heinsch, F. A., Reeves, M., Votava, P., Kang, S. Y., Milesi, C., Zhao, M. S., Glassy, J., Jolly, W. M., Loehman, R., Bowker, C. F., Kimball, J. S., Nemani, R. R., and Running, S. W.: User's Guide, GPP and NPP (MOD 17A2/A3) Products, NASA MODIS Land Algorithm [Online], available at: http://www.ntsg.umt.edu/modis/ MOD17UsersGuide.pdf, last access: 31 December 2009, 2003.

Ichii, K., Hashimoto, H., Nemani, R., and White, M.: Modeling the interannual variability and trends in gross and net primary pro- 
ductivity of tropical forests from 1982 to 1999 , Global Planet. Change, 48, 274-286, 2005.

Jung, M., Henkel, K., Herold, M., and Churkina, G.: Exploiting synergies of global land cover products for carbon cycle modeling, Remote Sens. Environ., 101, 534-553, 2006.

Kalnay, E., Kanamitsu, M., Kistler, R., Collins, W., Deaven, D., Gandin, L., Iredell, M., Saha, S., White, G., Woollen, J., Zhu, Y., Chelliah, M., Ebisuzaki, W., Higgins, W., Janowiak, J., Mo, K. C., Ropelewski, C., Wang, J., Leetmaa, A., Reynolds, R., Jenne, R., and Joseph, D.: The NCEP/NCAR 40-year reanalysis project, Bull. Am. Met. Soc., 77, 437-471, 1996.

Kaminski, T. and Heimann, M.: Inverse modeling of atmospheric carbon dioxide fluxes, Science, 294, 259, doi:10.1126/science.294.5541.259a, 2001.

Kaminski, T., Knorr, W., Rayner, P. J., and Heimann, M.: Assimilating atmospheric data into a terrestrial biosphere model: A case study of the seasonal cycle, Global Biogeochem. Cy., 16, 1066, doi:10.1029/2001GB001463, 2002.

Keenan, T. F., Baker, I., Barr, A., Ciais, P., Davis, K., Dietze, M., Dragoni, D., Gough, C. M., Grant, R., Hollinger, D., Hufkens, K., Poulter, B., McCaughey, H., Raczka, B., Ryu, Y., Schaefer, K., Tian, H., Verbeeck, H., Zhao, M., and Richardson, A.: Terrestrial biosphere model performance for inter-annual variability of landatmosphere $\mathrm{CO}_{2}$ exchange, Glob. Change Biol., 18, 1971-1987. doi:10.1111/j.1365-2486.2012.02678.x, 2012.

Knorr, W.: Annual and interannual $\mathrm{CO}_{2}$ exchanges of the terrestrial biosphere: process based simulations and uncertainties, Glob. Ecol. Biogeogr., 9, 225-252, 2000.

Knorr, W. and Heimann, M.: Impact of drought stress and other factors on seasonal land biosphere $\mathrm{CO}_{2}$ exchange studied through an atmospheric tracer transport model, Tellus B, 47, doi:10.1034/j.1600-0889.47.issue4.7.x, 1995.

Krakauer, N. Y. and Randerson, J. T.: Do volcanic eruptions enhance or diminish net primary production? Evidence from tree rings, Global Biogeochem. Cy., 17, 1118, doi:10.1029/2003GB002076, 2003.

Lloyd, J. and Taylor, J. A.: On the temperature dependence of soil respiration, Funct. Ecol., 8, 315-323, 1994.

Los, S. O., Pollack, N. H., Parris, M. T., Collatz, G. J., Tucker, C. J., Sellers, P. J., Malmström, C. M., DeFries, R. S., Bounoua, L., and Dazlich, D. A.: A Global 9-yr Biophysical Land Surface Dataset from NOAA AVHRR Data, J. Hydrometeorol., 1, 183199, 2000.

Mahecha, M. D., Reichstein, M., Carvalhais, N., lasslop, G., Lange, H., Seneviratne, S. I., Vargas, R., Ammann, C., Arain, M. A., Cescatti, A., Janssens, I. A., Migliavacca, M., Montagnani, L., and Richardson, A.: Global Convergence in the Temperature Sensitivity of Respiration at Ecosystem Level, Science, 329, 838-840, doi:10.1126/science.1189587, 2010.

Malmstrom, C. M., Thompson, M. V., Juday, G. P., Los, S. O., Randerson, J. T., and Field, C. B.: Interannual variation in globalscale net primary production: Testing model estimates, Global Biogeochem. Cy., 33, 481-486, 1997.

McGuire, A. D., Sitch, S., Clein, J. S., Dargaville, R., Esser, G., Foley, J., Heimann, M., Joos, F., Kaplan, J., Kicklighter, D. W., Meier, R. A., Melillo, J. M., Moore III, B., Prentice, I. C., Ramankutty, N., Reichenau, T., Schloss, A., Tian, H., Williams, L. J., and Wittenberg, U.: Carbon balance of the terrestrial biosphere in the twentieth century: Analyses of $\mathrm{CO}_{2}$, climate and land use effects with four process-based ecosystem models, Global Biogeochem. Cy., 15, 183-206, 2001.

Mercado, L., Bellouin, N., Sitch, S., Boucher, O., Huntingford, C., Wild, M., and Cox, P. M.: Impact of changes in diffuse radiation on the global land carbon sink, Nature, 458, 1014-1017, doi:10.1038/nature07949, 2009.

Migliavacca, M., Reichstein, M., Richardson, A. D., Colombo, R., Sutton, M. A., lasslop, G., Tomelleri, E., Wohlfahrt, G., Carvalhais, N., Cescatti, A., Mahecha, M. D. D., Montagnani, L., Papale, D., Zaehle, S., ARAIN, A., Arneth, A., Black, T. A., Carrara, A., Dore, S., Gianelle, D., helfter, C., Hollinger, D., Kutsch, W. L., Lafleur, P. M., Nouvellon, Y., Rebmann, C., da Rocha, H. R., Rodeghiero, M., Roupsard, O., Sebastià, M. T., Seufert, G., Soussana, J. F., and van der Molen, M. K. K.: Semiempirical modeling of abiotic and biotic factors controlling ecosystem respiration across eddy covariance sites, Global Change Biol., 17, 390-409, 2011.

Monteith, J. L.: Climate and efficiency of crop production in Britain, Philos. T. R. Soc. Lond., 281, 277-294, 1977.

Nemani, R. R. and Running, S. W.: Estimation of Regional Surface Resistance to Evapotranspiration from NDVI and ThermalIR AVHRR Data, J. Appl. Meteorol., 28, 276-284, 1989.

Nemani, R. R., Keeling, C. D., Hashimoto, H., Jolly, W. M., Piper, S. C., Tucker, C. J., Myneni, R. B., and Running, S. W.: Climatedriven increases in global terrestrial net primary production from 1982 to 1999, Science, 300, 1560-1563, 2003.

Nobel, P. S.: Phsiochemical and Environmental Plant Physiology, Academic Press, San Diego, California, 1991.

Oliveira, P. H. F., Artaxo, P., Pires, C., lucca, S. D., Procopio, A., Holben, B., Schafer, J., Cardoso, L. F., Wofsy, S. C., and Rocha, H. R.: The effects of biomass burning aerosols and clouds on the $\mathrm{CO}_{2}$ flux in Amazonia, Tellus B, 59, 338-349, 2007.

Pacala, S. W., Hurtt, G. C., Baker, D., Peylin, P., Houghton, R. A., Birdsey, R. A., Heath, L., Sundquist, E. T., Stallard, R. F., Ciais, P., Moorcroft, P., Caspersen, J. P., Shevliakova, E., Moore, B., Kohlmaier, G., Holland, E., Gloor, M., Harmon, M. E., Fan, S.M., Sarmiento, J. L., Goodale, C. L., Schimel, D., and Field, C. B.: Consistent land- and atmosphere-based U. S. carbon sink estimates, Science, 292, 2316-2320, 2001.

Potter, C., Klooster, S., Genovese, V., Hiatt, C., Boriah, S., Kumar, V., Mithal, V., and Garg, A.: Terrestrial Ecosystem Carbon Fluxes Predicted from MODIS Satellite Data and Large-Scale Disturbance Modeling, Int. J. Geosci., 3, 469-479, 2012.

Potter, C. S., Randerson, J. T., Field, C. B., Matson, P. A., Vitousek, P. M., Mooney, H. A., and Klooster, S. A.: Terrestrial ecosystem production: a process model based on global satellite and surface data, Global Biogeochem. Cy., 7, 811-841, 1993.

Raich, J. W. and Schlesinger, W. H.: The global carbon dioxide flux in soil respiration and its relationship to vegetation and climate, Tellus B, 44, 81-99, 1992.

Raich, J. W., Potter, C. S., and Bhagawati, D.: Interannual variability in global soil respiration, 1980-94, Global Change Biol., 8, 800-812, 2002.

Randerson, J. T., Thompson, M. V., Malmstrm̈, C. M., Field, C. B., and Fung, I. Y.: Substrate limitations for heterotrophs: Implications for models that estimate the seasonal cycle of atmospheric $\mathrm{CO}_{2}$, Global Biogeochem. Cy., 10, 585-602, doi:10.1029/96GB01981, 1996. 
Randerson, J. T., van der Werf, G. R., Collatz, G. J., Giglio, L., Still, C. J., Kasibhatla, P., Miller, J. B., White, J. W. C., DeFries, R. S., and Kasischke, E. S.: Fire emissions from $\mathrm{C}_{3}$ and $\mathrm{C}_{4}$ vegetation and their influence on interannual variability of atmospheric $\mathrm{CO}_{2}$ and $\delta^{13} \mathrm{CO}_{2}$, Global Biogeochem. Cy., 19, GB2019, doi:10.1029/2004GB002366, 2005.

Rayner, P. J., Scholze, M., Knorr, W., Kaminski, T., Giering, R., and Widmann, H.: Two decades of terrestrial carbon fluxes from a carbon cycle data assimilation system (CCDAS), Global Biogeochem. Cy., 19, 20 pp., doi:10.1029/2004GB002254, 2005.

Reichstein, M., Rey, A., Freibauer, A., Tenhunen, J., Valentini, R., Banza, J., Casals, P., Cheng, Y. F., Grünzweig, J. M., Irvine, J., Joffre, R., Law, B. E., Loustau, D., Miglietta, F., Oechel, W., Ourcival, J.-M., Pereira, J. S., Peressotti, A., Ponti, F., Qi, Y., Rambal, S., Rayment, M., Romanya, J., Rossi, F., Tedeschi, V., Tirone, G., Xu, M., and Yakir, D.: Modeling temporal and largescale spatial variability of soil respiration from soil water availability, temperature and vegetation productivity indices, Global Biogeochem. Cy., 17, 1104, doi:10.1029/2003GB002035, 2003.

Reichstein, M., Kätterer, T., Andrén, O., Ciais, P., Schulze, E.-D., Cramer, W., Papale, D., and Valentini, R.: Temperature sensitivity of decomposition in relation to soil organic matter pools: critique and outlook, Biogeosciences, 2, 317-321, doi:10.5194/bg2-317-2005, 2005.

Rödenbeck, C.: Estimating $\mathrm{CO}_{2}$ sources and sinks from atmospheric mixing ratio measurements using a global inversion of atmospheric transport, Tech. Rep. 6, Max Planck Institute for Biogeochemistry, Jena, Germany, 2005.

Rödenbeck, C., Houweling, S., Gloor, M., and Heimann, M.: $\mathrm{CO}_{2}$ flux history 1982-2001 inferred from atmospheric data using a global inversion of atmospheric transport, Atmos. Chem. Phys., 3, 1919-1964, doi:10.5194/acp-3-1919-2003, 2003.

Running, S. W., Nemani, R. R., Glassy, J. M., and Thornton, P. E.: MODIS Daily Photosynthesis (PSN) and Annual Net Primary Production (NPP) Product (MOD17), Tech. rep., NASA, 1999.

Running, S. W., Nemani, R. R., Heinsch, F. A., Zhao, M. S., Reeves, M., and Hashimoto, H.: A continuous satellite-derived measure of global terrestrial primary production, Bioscience, 54, 547560, 2004.

Scholze, M., Kaplan, J. O., Knorr, W., and Heimann, M.: Climate and interannual variability of the atmosphere-biosphere $13 \mathrm{CO}_{2}$ flux, Geophys. Res. Lett., 30, 4 pp., doi:10.1029/2002GL015631, 2003.

Schwalm, C., Williams, C. A., Schaefer, K., Anderson, R., Arain, M. A., Baker, I., Barr, A., Black, T. A., Chen, G. S., Chen, J. M., Ciais, P., Davis, K. J., Desai, A., Dietze, M., Dragoni, D., Fischer, M. L., Flanagan, L. B., Grant, R., Gu, L. H., Hollinger, D., Izaurralde, R. C., Kucharik, C., Lafleur, P. M., Law, B. E., Li, L. H., Li, Z. P., Liu, S. G., Lokupitiya, E., Luo, Y. Q., Ma, S. Y., Margolis, H., Matamala, R., McCaughey, H., Monson, R. K., Oechel, W. C., Peng, C. H., Poulter, B., Price, D. T., Riciutto, D. M., Riley, W., Sahoo, A. K., Sprintsin, M., Sun, J. F., Tian, H. Q., Tonitto, C., Verbeeck, H., and Verma, S. B.: A model-data intercomparison of $\mathrm{CO}_{2}$ exchange across North America: Results from the North American Carbon Program site synthesis, J. Geophys. Res., 115, 22 pp., doi:10.1029/2009JG001229, 2010.

Sellers, P. J.: Canopy reflectance, photosynthesis and transpiration, Int. J. Remote Sens., 6, 1335-1372, 1985.
Sellers, P. J., Los, S. O., Tucker, C. J., Justice, C. O., Dazlich, D. A., Collatz, G. J., and Randall, D. A.: A revised land surface parameterization ( $\mathrm{SiB} 2)$ for atmospheric GCMs, Part II: The generation of global fields of terrestrial biophysical parameters from satellite data, J. Climate, 9, 706-737, 1996a.

Sellers, P. J., Randall, D. A., Collatz, G. J., Berry, J. A., Field, C. B., Dazlich, D. A., Zhang, C., Collelo, C. D., and Bounoua, L.: A revised land surface parameterization (SiB2) for atmospheric GCMs: Part 1. Model formulation, J. Climate, 9, 676705, 1996 b.

Sitch, S., Huntingford, C., Gedney, N., Levy, P., Lomas, M., Piao, S., Betts, R., Ciais, P., Cox, P., Friedlingstein, P., Jones, C. D., Prentice, I. C., and Woodward, F. I.: Evaluation of the terrestrial carbon cycle, future plant geography and climate-carbon cycle feedbacks using five Dynamic Global Vegetation Models (DGVMs), Global Change Biol., 14, 2015-2039, 2008.

Stephenson, N. L.: Climatic control of vegetation distribution: the role of the water balance, The American Naturalist, 135, 649670, 1990.

Stoy, P., Katul, G., Siqueira, M., Juang, J.-Y., McCarthy, H., Kim, H.-S., Oishi, A., and Oren, R.: Variability in net ecosystem exchange from hourly to inter-annual time scales at adjacent pine and hardwood forests: a wavelet analysis, Tree Physiol., 25, 887902, 2005.

Thornton, P. E., Running, S. W., and Hunt, E. R.: Biome-BGC: Terrestrial Ecosystem Process Model, Version 4.1.1. Data model, Oak Ridge National Laboratory Distributed Active Archive Center, Oak Ridge, Tennessee, U.S.A, http://www.daac.ornl.gov, last access: December 2010, 2005.

Trusilova, K. and Churkina, G.: The terrestrial ecosystem model BIOME-BGC v1, Tech. Rep. 14, MPI BGC, Jena (Germany), 2008.

Trusilova, K., Trembath, J., and Churkina, G.: Parameter estimation and validation of the terrestrial ecosystem model BIOMEBGC using eddy-covariance flux measurments, Tech. Rep. 16, MPI BGC, Jena, Germany, 2009.

Tucker, C. J., Pinzon, J. E., Brown, M. E., Slayback, D., Pak, E. W., Mahoney, R., Vermote, E. F., and Saleous, N. E.: An Extended AVHRR 8-km NDVI Data Set Compatible with MODIS and SPOT Vegetation NDVI Data, Int. J. Remote Sens., 26, 44855598, 2005.

Turner, D. P., Goeckede, M., Law, B., Ritts, W., Cohen, W., Yang, Z., Hudiburg, T., Kennedy, R., and Duane, M.: Multiple constraint analysis of regional land-surface carbon flux, Tellus B, 63, 207-221, 2011.

Valentini, R., Matteucci, G., Dolman, A. J., Schulze, E.-D., Rebmann, C., Moors, E. J., Granier, A., Gross, P., Jensen, N. O., Pilegaard, K., Lindroth, A., Grelle, A., Bernhofer, C., Grünwald, T., Aubinet, M., Ceulemans, R., Kowalski, A. S., Vesala, T., Rannik, Ü., Berbigier, P., Loustau, D., Guomundsson, J., Thorgeirsson, H., Ibrom, A., Morgenstern, K., Clement, R., Moncrieff, J., Montagnani, L., Minerbi, S., and Jarvis, P. G.: Respiration as the main determinant of carbon balance in European forests, Nature, 404, 861-865, 2000.

van der Werf, G. R., Randerson, J. T., Collatz, G. J., Giglio, L., Kasibhatla, P., Arellano, A., Olsen, S. C., and Kasischke, E. S.: Continental-scale partitioning of fire emissions during the 1997 to $2001 \mathrm{El} \mathrm{Nino/La} \mathrm{Nina} \mathrm{period,} \mathrm{Science,} \mathrm{303,} \mathrm{73-76,} 2004$. 
van der Werf, G. R., Randerson, J. T., Giglio, L., Collatz, G. J., Mu, M., Kasibhatla, P. S., Morton, D. C., DeFries, R. S., Jin, Y., and van Leeuwen, T. T.: Global fire emissions and the contribution of deforestation, savanna, forest, agricultural, and peat fires (1997-2009), Atmos. Chem. Phys. Discuss., 10, 16153-16230, doi:10.5194/acpd-10-16153-2010, 2010.
Wang, T., Ciais, P., Piao, S. L., Ottlé, C., Brender, P., Maignan, F., Arain, A., Cescatti, A., Gianelle, D., Gough, C., Gu, L., Lafleur, P., Laurila, T., Marcolla, B., Margolis, H., Montagnani, L., Moors, E., Saigusa, N., Vesala, T., Wohlfahrt, G., Koven, C., Black, A., Dellwik, E., Don, A., Hollinger, D., Knohl, A., Monson, R., Munger, J., Suyker, A., Varlagin, A., and Verma, S.: Controls on winter ecosystem respiration in temperate and boreal ecosystems, Biogeosciences, 8, 2009-2025, doi:10.5194/bg8-2009-2011, 2011. 